\title{
Barrier Effect on MJO Propagation by the Maritime Continent in the MJO Task Force/GEWEX Atmospheric System Study Models
}

\author{
JiAn Ling, YUQING ZHAO, AND GUIWAN CHEN \\ State Key Laboratory of Numerical Modeling for Atmospheric Sciences and Geophysical Fluid Dynamics, Institute of \\ Atmospheric Physics, and University of Chinese Academy of Sciences, Chinese Academy of Sciences, Beijing, China
}

(Manuscript received 18 December 2018, in final form 30 May 2019)

\begin{abstract}
The simulated Madden-Julian oscillation (MJO) events in 27 general circulation models (GCMs) are identified using an MJO tracking method. The results suggest that the occurrence frequencies of simulated MJO events can represent a model's ability to simulate several characteristics of the MJO to a certain extent during boreal winter, such as propagation range, strength, and termination longitude. All tracked MJO events are classified into those that propagate through the Maritime Continent (MC) (MJO-C) and those that do not (MJO-B), and the weakening and blocking effects on MJO propagation by the MC in GCMs were quantified. In general, if a GCM shows a stronger weakening effect on MJO strength over the MC, it tends to produce a stronger blocking effect on MJO propagation over the MC during boreal winter. The barrier effect of the MC on MJO propagation is exaggerated in most GCMs, while it can be underestimated in some GCMs, especially the coupled GCMs. Strong lower-tropospheric premoistening is identified ahead of the MJO convection center when it is over the central MC for MJO-C but not for MJO-B in most GCMs. Such strong premoistening is mainly attributed to the zonal gradient of lower-tropospheric easterly anomalies within the front Walker cell, which could be a precursor leading to the eastward propagation of MJO convection. In contrast to the observation, the role of the background sea surface temperature and land-sea precipitation contrast in the barrier effect on MJO propagation by the MC is not well captured by most GCMs.
\end{abstract}

\section{Introduction}

The Madden-Julian oscillation (MJO; Madden and Julian 1971, 1972) is the dominant component of intraseasonal (30-90 days) variability in the tropics. It consists of a circulation of planetary zonal scales coupled with organized deep convection. Its convection usually forms over the central Indian Ocean, propagates eastward across the Indo-Pacific Maritime Continent (MC) and warm pool along the equator at an average speed of about $5 \mathrm{~m} \mathrm{~s}^{-1}$, and disappears over the central Pacific (Zhang 2005). The MJO plays a crucial role in connecting weather and climate (Zhang 2013) and is considered one of the primary sources of predictability on the subseasonal (10-40 days) time scale (Waliser et al. 2003). When propagating eastward, MJO can affect global weather and climate systems, such as the Asian and Australian summer monsoons (Wheeler and McBride 2005; Hsu and Yang 2016), tropical cyclones (Liebmann et al. 1994), and El Niño-Southern Oscillation (ENSO)

\footnotetext{
Corresponding author: Jian Ling, lingjian@lasg.iap.ac.cn
}

(Kessler and Kleeman 2000; Zhang and Gottschalck 2002).

The characteristics of MJO propagation over the MC are different from those over the open oceans. By tracking eastward propagation of MJO precipitation, Zhang and Ling (2017) demonstrated that about half the MJO events formed over the Indian Ocean failed to propagate through the $\mathrm{MC}$, and more than $75 \%$ of the MJO events that propagate through the MC became weakened over the MC. Such weakening and blocking of MJO propagation over the MC is known as the "barrier effect" of the MC. Previous studies indicated that this barrier effect is usually exaggerated in numerical models (Kim et al. 2009; Seo et al. 2009; Wang et al. 2014) and can lead to a "prediction barrier" in numerical prediction (Weaver et al. 2011; Fu et al. 2013). Such a prediction barrier would hinder the overall subseasonal prediction (Hendon et al. 2000). Vitart and Molteni (2010) indicated that MJO events were more likely to terminate over the MC in the ECMWF forecast systems than its global reanalysis. Wang et al. (2019) found that prediction skill for MJO convection is lowest 
when it is over the MC during boreal winter in most $\mathrm{WMO} /$ subseasonal to seasonal (S2S) models.

Several possible reasons were proposed to explain the MC barrier effect on MJO propagation. They include the reduced surface flux due to the islands of the MC (Maloney and Sobel 2004; Sobel et al. 2008), distorted low-level circulation by topography (Hsu and Lee 2005; Inness and Slingo 2006; Wu and Hsu 2009), strong persistent diurnal convection over major islands (Neale and Slingo 2003; Hagos et al. 2016; Wang and Sobel 2017; Ling et al. 2019), impacts of shorter-time-scale monsoon processes in the western MC (Chang et al. 2005), the downstream large-scale circulations over the western Pacific (Kim et al. 2014; Feng et al. 2015), and the sea surface temperature (SST) anomaly over the central-toeastern Pacific (Liu et al. 2016a,b; Chen et al. 2016). Zhang and Ling (2017) suggested stronger zonal moisture flux convergence in lower troposphere and higher SST over the MC region could help the MJO to overcome this barrier effect. Chen and Wang (2018) suggested that leading suppressed convection (LSC) along with a front Walker cell (FWC) over the MC and the western Pacific when MJO convection is over the Indian Ocean could help the MJO to propagate through the MC.

Realistic climate modeling of the MJO has always been a challenge since the discovery of the MJO (Hayashi and Golder 1986; Lau and Lau 1986; Slingo et al. 1996; Sperber et al. 1997; Waliser et al. 2003; Lin et al. 2006; Zhang et al. 2006; Kim et al. 2009; Hung et al. 2013; Jiang et al. 2015). Even though progress has been made during the past decades, most state-of-the-art general circulation models (GCMs) still cannot produce certain characteristics of the MJO (Zhang 2005; Hung et al. 2013; Jiang et al. 2015), for example, its amplitude, eastward-propagation speed, and seasonal cycle. Hung et al. (2013) indicated only one GCM was able to simulate the observed eastward propagation of the MJO in phase 5 of the Coupled Model Intercomparison Project (CMIP5). Jiang et al. (2015) showed that only a quarter of the GCMs that participated in the MJO Task Force (MJOTF) (Moncrieff et al. 2012; Waliser et al. 2012) and the GEWEX Atmospheric System Study (GASS) (Petch et al. 2011; we refer to this by the abbreviation MJOTF/ GASS in this study) could produce the systematic eastward propagation of the MJO and suggested that environment moisture, convection-circulation feedback, and air-sea interaction can significantly impact MJO simulations. Jiang et al. (2016) further suggested simulated MJO amplitude is closely related to convective moisture adjustment time scale. Wang et al. (2017) suggested the zonal asymmetry in column-integrated moist static energy (MSE) is important to simulating realistic eastward propagation of the MJO from the same sets of GCMs. Wang and Lee (2017) indicated that if a GCM reproduces the zonal structure of the MJO with stronger Kelvin easterlies than Rossby westerlies in the lower troposphere, it produces the observed eastward propagation of the MJO.

All aforementioned results are based on the methods of extracting statistical signals of the MJO from GCMs, such as time-lag correlation and time-space spectra of certain variables ( Lin et al. 2006; Kim et al. 2009; Waliser et al. 2009; Hung et al. 2013; Jiang et al. 2015). Few studies of MJO simulations focused on the characteristics of individual MJO events in multiyear simulations. Ling et al. (2017) tracked individual MJO events in the MJOTF/GASS GCMs, and suggested that all GCMs could produce large-scale slowly eastward-propagating precipitation anomalies, and the difference is that some GCMs produced them frequently and others infrequently. This tracking method allows quantitative evaluation of the barrier effect on MJO propagation by the MC, which cannot be obtained by the statistical method mentioned above. The precipitation-centric view of the MJO diagnostics may also address other important problems in MJO simulations.

Motivated by this, in this study we quantitatively evaluate the barrier effect on $\mathrm{MJO}$ propagation over the MC in 27 GCMs that participated in the MJOTF/GASS following Zhang and Ling (2017), and identify mechanisms for MJO events to overcome the barrier effect. The MJO tracking method (Ling et al. 2014; Zhang and Ling 2017) was applied to identify individual MJO events based on intraseasonally filtered precipitation anomalies in both GCMs and observations. We introduce the data and method in section 2, present the results in section 3 , and discuss their implications in section 4 .

\section{Data and method}

Daily precipitation from Tropical Rainfall Measuring Mission (TRMM) 3B42, version 7, Multisatellite Precipitation Analysis (TMPA; Huffman et al. 2007) from 1998 to 2015 with a horizontal resolution of $0.25^{\circ} \times 0.25^{\circ}$ is used to identify individual MJO events in the observation. Other variables covering the same period are three-dimensional wind fields, air temperature, specific humidity $\left(0.75^{\circ} \times 0.75^{\circ}\right)$ provided by European Centre for Medium-Range Weather Forecasts interim reanalysis (ERA-I) (Dee et al. 2011) and NOAA Optimum Interpolation (OI) High Resolution Sea Surface Temperature, version 2 (OISSTv2; Reynolds et al. 2007), with a horizontal resolution of $0.25^{\circ} \times 0.25^{\circ}$ provided by NOAA/OAR/ESRL. For consistency with model 
outputs, all observations were interpolated to the same spatial grids $\left(2.5^{\circ} \times 2.5^{\circ}\right)$ as model outputs.

Twenty-seven climate simulations are from global multimodel evaluation project on vertical structure and diabatic processes of the MJO launched by the MJOTF/ GASS. Most simulations were integrated for 20 years using external forcing from 1991 to 2010 . They provided 6-hourly outputs interpolated into $2.5^{\circ} \times 2.5^{\circ}$ horizontal resolutions and 22 vertical pressure levels. Out of 27 GCMs, 20 are uncoupled models, 6 are fully coupled models, and 1 is a partially coupled model. Their detailed descriptions are available in Jiang et al. (2015). Daily data generated from 6-hourly outputs were used in this study.

Not all simulations provided the temperature tendency terms. For fair comparisons among all models, diabatic heating is estimated as the residual of the potential temperature equation following Yanai et al. (1973), which is known as the apparent heat source $\left(Q_{1}\right)$ :

$$
Q_{1}=\frac{T}{\theta}\left(\frac{\partial \theta}{\partial t}+u \frac{\partial \theta}{\partial x}+v \frac{\partial \theta}{\partial y}+\omega \frac{\partial \theta}{\partial p}\right)
$$

where $u, v$, and $\omega$ are the three-dimensional wind components; and $\theta=T\left(p_{0} / p\right)^{R / c_{p}}$ is the potential temperature, where $T$ is the temperature, $p$ is the pressure, $p_{0}$ is the pressure at $1000 \mathrm{hPa}$ in pressure coordinates, $c_{p}$ is the specific heat capacity of dry air, and $R$ is the specific gas constant of dry air.

The MJO tracking method (Ling et al. 2014; Zhang and Ling 2017) identifies individual MJO events by tracking eastward-propagating positive precipitation anomalies along the equator based on several known observed characteristics of the MJO. The tracking method can provide starting and ending longitudes, propagation ranges, duration, and strength for identified MJO events, which are not available from other MJO indices (Wheeler and Hendon 2004; Kiladis et al. 2014; Lafleur et al. 2015; Liu et al. 2016). A detailed description of this method is available in Zhang and Ling (2017).

Daily anomalies were first obtained by removing the daily climatology (omitting 29 February in leap years). The MJO tracking method was then applied to tropicalaveraged, intraseasonally filtered (zonal wavenumbers 1-10, and 20-100 day) daily precipitation anomalies from both observation and simulations using the same configuration parameters following Zhang and Ling (2017). The intraseasonal filtering in this study retains both eastward- and westward-propagating signals. It is inappropriate to retain only eastward-propagating signals for GCMs, in which westward-propagating signals cannot be ignored (Zhang et al. 2006; Jiang et al. 2015).

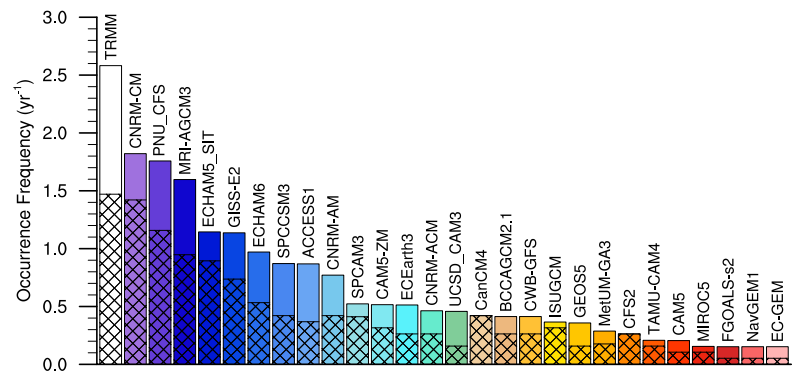

FIG. 1. Occurrence frequencies $\left(\mathrm{yr}^{-1}\right)$ of MJO events in the observation (TRMM) and GCMs. The cross marks the occurrence frequency during boreal winter.

MJO signals in GCM simulation would be overestimated if only eastward-propagating signals were retained. Three months of data at both beginning and end of the time series are discard because of the filtering. Only the tracked MJO events that propagated through the eastern Indian Ocean and entered the MC (viz., their initial longitudes were west of $90^{\circ} \mathrm{E}$ and terminal longitudes were east of $100^{\circ} \mathrm{E}$ ) were evaluated in this study.

\section{Results}

\section{a. MJO simulation skills}

Ling et al. (2017) pointed out that the occurrence frequency of simulated $\mathrm{MJO}$ events could represent the MJO simulation ability of a GCM. All GCMs underestimate the occurrence frequency of the MJO compared to the observation (Fig. 1). In more than $89 \%$ of the GCMs, occurrence frequencies of the MJO are only less than half those in observation, and in more than $67 \%$ of the GCMs they are only less than a quarter. In the observation, the occurrence frequency of MJO events during boreal summer is less than that during boreal winter. Even if the overall occurrence frequencies of the MJO are underestimated in all GCMs, the higher occurrence frequencies during boreal winter than boreal summer are captured by most GCMs, but they are overestimated.

If the $27 \mathrm{GCMs}$ are treated as independent samples, the correlation between their occurrence frequencies of the MJO and other corresponding MJO characteristics is significant at the $99 \%$ confidence level when the correlation coefficient exceeds 0.48 . In general, if a GCM produces $\mathrm{MJO}$ events more frequently, it has a higher chance to produce MJO events that propagate longer (Fig. 2a) with greater strength (Fig. 2b) and disappear farther east into the eastern Pacific (Fig. 2c) during boreal winter. The smaller correlation in boreal summer (Figs. 2d-f) may be related to the northward-propagation component of the MJO induced by the Asian summer 
(a)

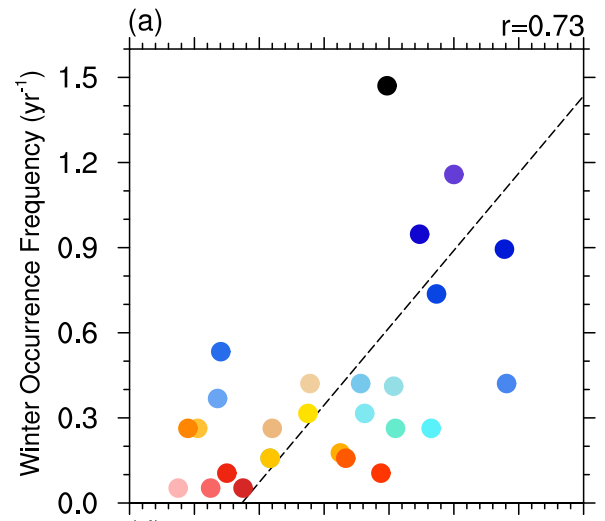

(d)

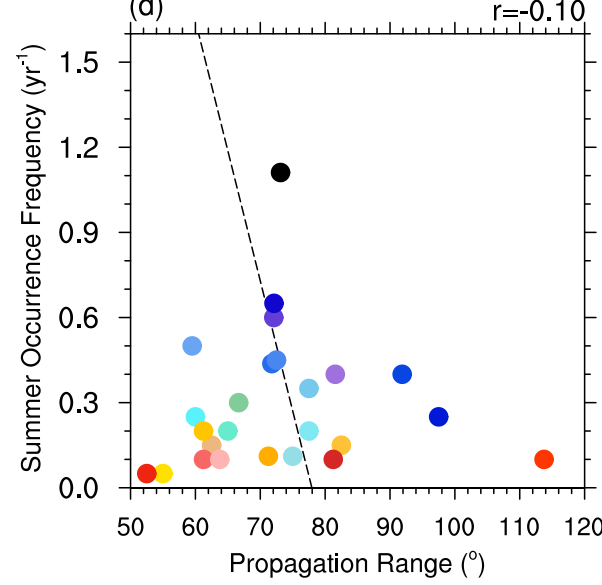

(b)

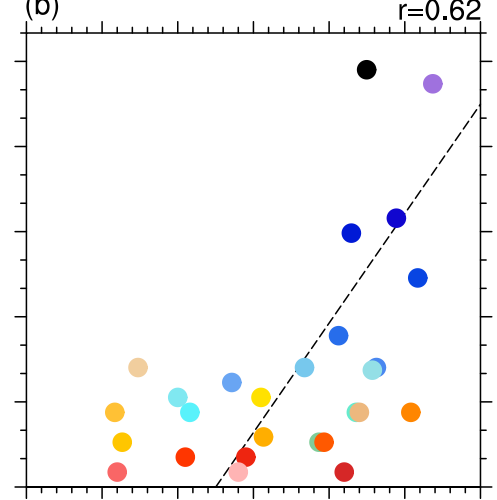

(e)

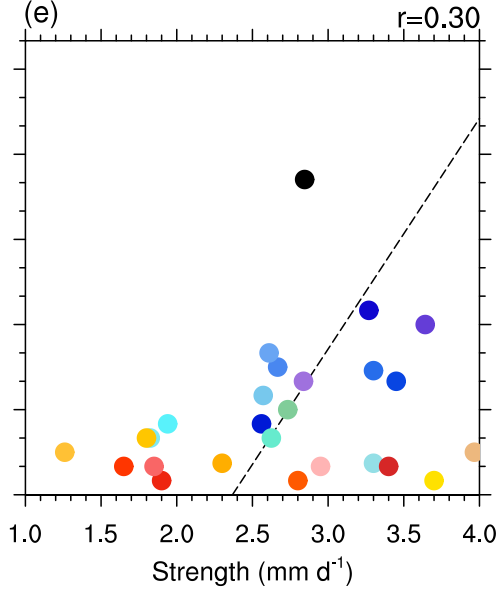

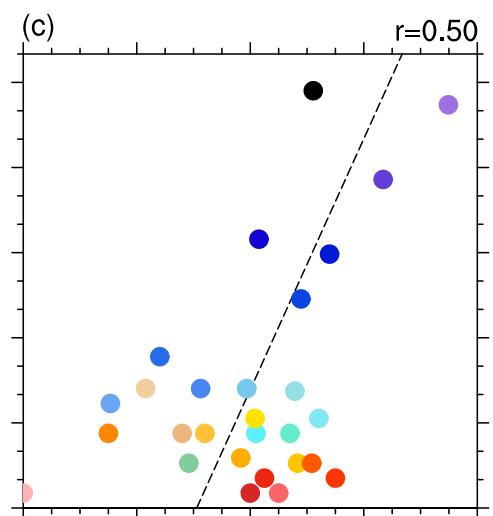
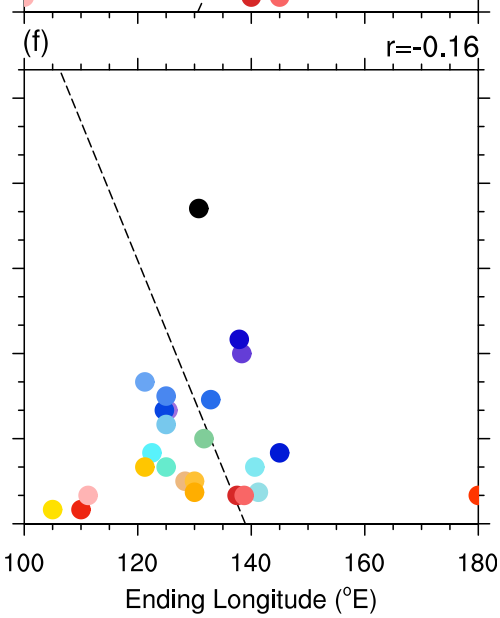

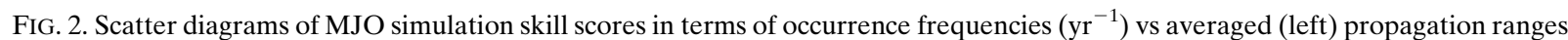
(longitude), (middle) strength $\left(\mathrm{mm} \mathrm{day}^{-1}\right)$, and (right) ending longitude $\left({ }^{\circ} \mathrm{E}\right)$ of tracked MJO events in the observations and GCMs for the (top) boreal winter and (bottom) boreal summer. Their correlation coefficients are given on the top right corners. The black dots represent the observations and the color dots represent the model simulations shown in Fig. 1.

monsoon (Wang and Rui 1990; Li et al. 2001). The initiation locations of MJO events are more or less evenly distributed over the Indo-Pacific region in GCMs, while most MJO events form over the Indian Ocean in the observations (Ling et al. 2017). Therefore, the termination longitude (Fig. 2c) does not show comparable correlation with the occurrence frequencies of the $\mathrm{MJO}$ as the propagation range. CNRM-CM was suggested to be one of the best GCMs in CMIP3 and CMIP5 in simulating the tropical intraseasonal variability ( $\mathrm{Lin}$ et al. 2006), and it is the only GCM to simulate the realistic eastward propagation of MJO (Hung et al. 2013). It produced the highest occurrence frequency of MJO events among all GCMs, but the amplitude (Fig. 2b) and the propagation range (Fig. 2a) of the simulated MJO are overestimated compared to the observation.

In the observation, MJO events tend to be stronger, propagate longer, and terminate farther east into the eastern Pacific during the boreal winter (black dots in Fig. 2) than boreal summer, and their differences are well demonstrated in the composite time-longitude of anomalous precipitation for the tracked MJO events (Fig. 3). In the GCMs, the MJO events also tend to be stronger during boreal winter and propagate longer (Figs. 2 and 3) than during boreal summer.

The above results confirm that the occurrence frequencies of MJO events can be used to measure MJO simulation ability for GCMs to a certain extent in boreal winter. Most GCMs show worse MJO simulation skills during boreal summer because the eastward propagation of the MJO can be affected by northward-propagation component of the MJO induced by the Asian summer monsoon. Another possible reason is there are lots of larger islands over the northern MC that may block the eastward propagation of the MJO during boreal summer (Zhang and Ling 2017).

\section{b. MC barrier effect on MJO propagation}

The zonal distributions of termination frequencies of MJO events as a function of ending longitudes in observations and all GCMs are shown in Fig. 4. The two peaks in observed termination frequencies (Figs. 4a,b) 

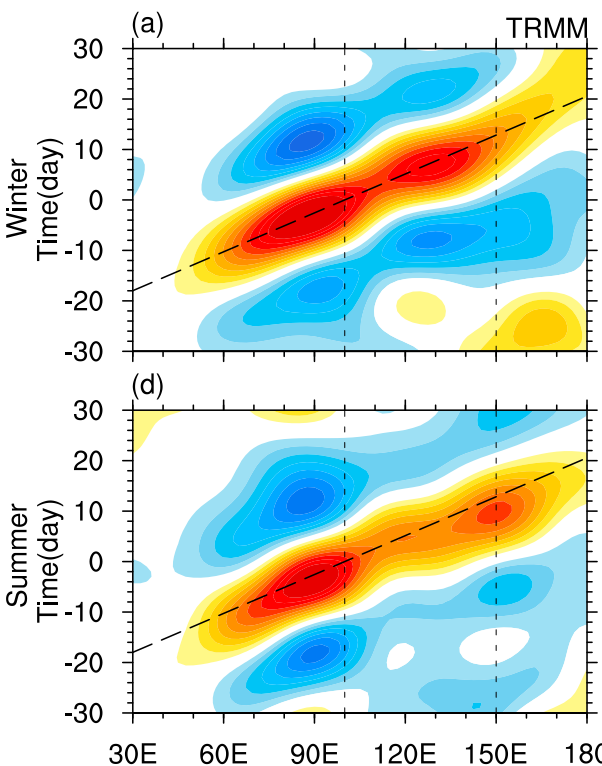

(b)

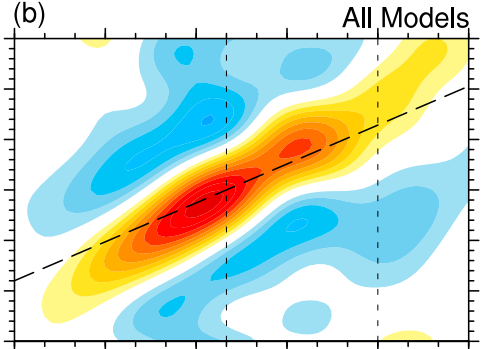

(e)

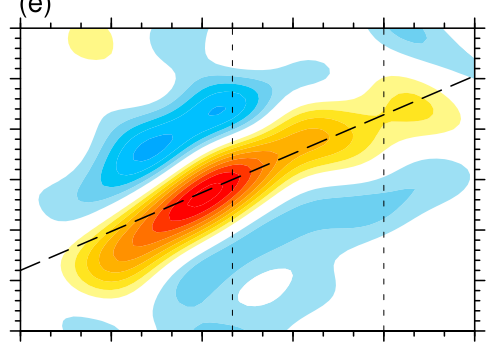

$(\mathrm{f})$
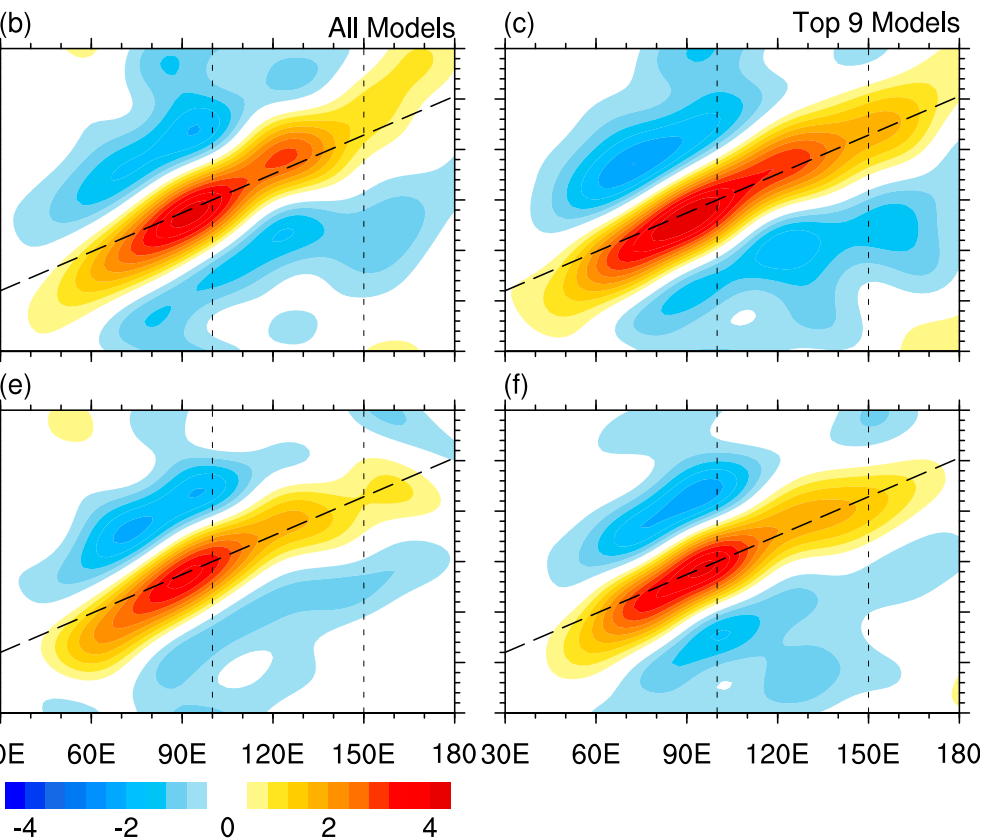

FIG. 3. Time-longitude diagrams of composited tracked MJO precipitation anomalies $\left(\mathrm{mm} \mathrm{day}^{-1}\right)$ averaged over $15^{\circ} \mathrm{S}-15^{\circ} \mathrm{N}$ in the $(\mathrm{left})$ TRMM, and (middle) all and (right) top 9 GCMs as ranked in Fig. 1 during (top) boreal winter, and (bottom) boreal summer. Time 0 is when an MJO track crosses $100^{\circ} \mathrm{E}$. The dashed straight lines mark the $5 \mathrm{~m} \mathrm{~s}^{-1}$ eastward propagation speed, and the dashed vertical lines marks the west and east boundary of the MC.

suggest two distinct categories of the MJO. MJO events either fail to propagate through the MC, or they propagate through the $\mathrm{MC}$ and vanish around the central Pacific. In this study, the MJO events successful in crossing the $\mathrm{MC}$ were referred to as $\mathrm{MJO}-\mathrm{C}$ (ending at longitudes east of $150^{\circ} \mathrm{E}$ ), while those that were not successful were referred to as MJO-B (ending at longitudes within $100^{\circ}-150^{\circ} \mathrm{E}$ ) following Zhang and Ling (2017). In GCMs, there is only one distinct peak over the $\mathrm{MC}$, indicating most simulated $\mathrm{MJO}$ events fail to propagate through the $\mathrm{MC}$ and vanish there.

Distinct seasonal dependence is observed in the termination locations of the MJO. In the observation, most
MJO-B events tend to vanish over the eastern MC (peak around $150^{\circ} \mathrm{E}$ ) during boreal winter, while they tend to vanish over the western $\mathrm{MC}$ (peak around $120^{\circ} \mathrm{E}$ ) during boreal summer. Meanwhile, MJO-C events propagate farther east into the eastern Pacific during boreal winter. All suggest a larger barrier effect on MJO propagation over the MC during boreal summer than winter in the observation. The seasonal characteristics of the barrier effect on MJO propagation are well captured by the GCMs in spite of the overall significantly underestimated occurrence frequencies of the MJO.

In this study, the blocking effect on MJO propagation by the MC was quantified in terms of the ratio of the (a) Winter

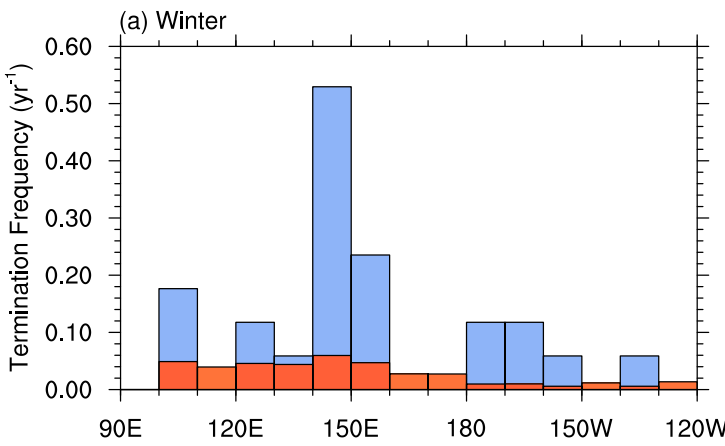

(b) Summer

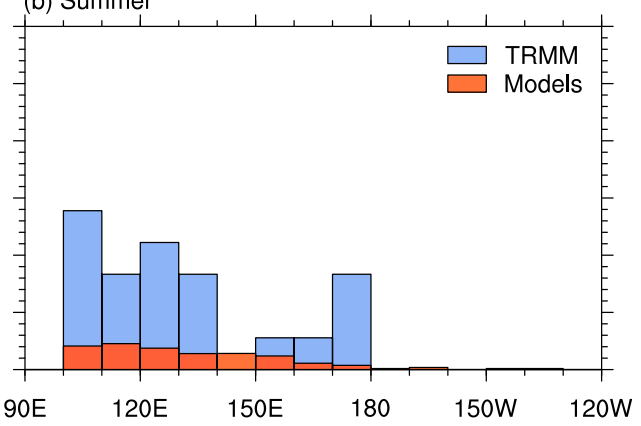

FIG. 4. Distributions of termination frequencies of tracked MJO events that start over the Indian Ocean as a function of ending longitude for the TRMM and GCMs composites during (a) boreal winter and (b) summer. 


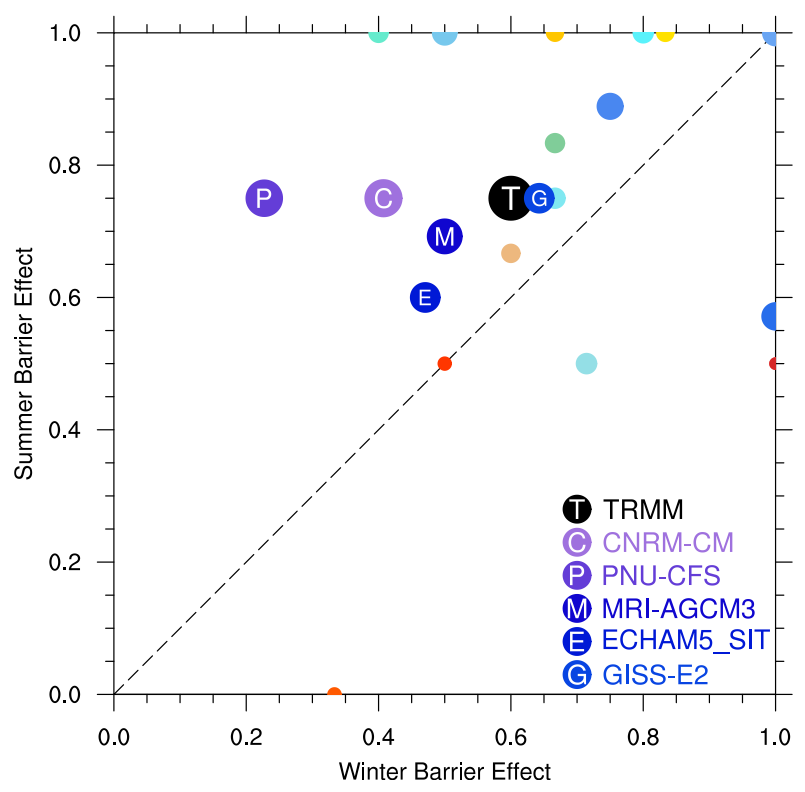

FIG. 5. Scatter diagrams of the barrier effect during boreal winter vs that during boreal summer in the TRMM and GCMs. The black dots represent the TRMM and the color dots represent GCMs shown in Fig. 1. The radii of the dots are proportional to the total occurrence frequencies of the MJO events from each dataset.

number of MJO-B events to the total number of MJO events entering the MC. The blocking effect on MJO propagation is $60 \%$ during boreal winter and $75 \%$ during boreal summer in the observation, while it increases to $70 \%$ during boreal winter and $77 \%$ during boreal summer in the GCM simulations (Fig. 5). The evaluated observed blocking effects in this study are generally stronger than those in Zhang and Ling (2017) because both westward- and eastward-propagating signals were retained in filtering in this study, while only eastwardpropagating signals were retained in Zhang and Ling (2017). In general, the blocking effects on MJO propagation were exaggerated in most GCMs during both boreal summer and winter. However, there are still several GCMs that could produce comparable or even weaker blocking effects on MJO propagation by the $\mathrm{MC}$, compared to the observation.

The occurrence frequencies of MJO events are limited in most GCMs, especially during boreal summer; therefore, only the GCMs that can produce more than $10 \mathrm{MJO}$ events during boreal winter within a $20-\mathrm{yr}$ simulation are further examined in the following sections. Only five GCMs meet this criterion, and all are thought to be good at producing MJO propagation characteristics based on the statistical evaluation methods (Jiang et al. 2015). Three are coupled GCMs [Pusan National University Climate Forecast System (PNU-CFS), CNRM-CM, and ECHAM5 with Snow-Ice-Thermocline
Coupler (ECHAM5-SIT)] and two are uncoupled GCMs (MRI-AGCM3 and GISS-E2). It should be noted that the mean blocking effects of the three coupled models are weaker than those of uncoupled models, implying air-sea coupling could help MJO to propagate through the MC. Air-sea coupling could increase the amplitude of positive SST anomalies on the intraseasonal time scale ahead of the convection over the MC to favor propagation of the MJO through the MC by affecting the heat fluxes (Lindzen and Nigam 1987; Hsu and Li 2012; Hirata et al. 2013).

Besides the blocking effect on MJO propagation, Zhang and Ling (2017) also pointed out that the MC can weaken the MJO events. Based on TMPA precipitation, the strength of most tracked MJO events decreases over the $\mathrm{MC}$ and recovers over the western Pacific (around $150^{\circ} \mathrm{E}$ ) for MJO-C (Fig. 6a), while it never recovers and vanishes over the $\mathrm{MC}$ for MJO-B (Fig. 6g). CNRM-CM shows the weakest blocking effect, but the evolution of the MJO strength along the equator is very different from that in the observation and the other four models. In CNRM-CM, the strength of most tracked MJO events does not decrease over the $\mathrm{MC}$, and their strength continues to increase for MJO-C over the MC (Fig. 6b), while their strength starts to decrease when crossing the central MC for MJO-B (Fig. 6h). For the remaining four models, their strength evolution along the equator is similar to that in the observation (Figs. 6c-f), except for the locations of the maximum strength of MJO-C events. No systematic difference was identified in locations of the maxima strength over the MC between coupled and uncoupled GCMs.

If a tracked $\mathrm{MJO}$ event over the $\mathrm{MC}\left(120^{\circ}-125^{\circ} \mathrm{E}\right)$ is weaker than before it enters the $\mathrm{MC}\left(90^{\circ}-100^{\circ} \mathrm{E}\right.$ in this study), it is treated as a weakened MJO event by the $\mathrm{MC}$. The weakening effect on the MJO over the MC is then quantitatively measured by the ratio of the number of weakened $\mathrm{MJO}$ events to the total number of $\mathrm{MJO}$ events that enter the MC. In the observation, $50 \%$ of the MJO-C events are weakened over the MC (Fig. 6a), while $66 \%$ of the MJO-B events are weakened (Fig. $6 \mathrm{~g}$ ). The difference between current results and Zhang and Ling (2017) can also be traced to the different filtering mentioned above. Out of all tracked MJO-C events, $19 \%$ are weakened in CNRM-CM, $18 \%$ in PNU-CFS, $33 \%$ in ECHAM5-SIT, 78\% in MRI-AGCM, and $40 \%$ in GISS-E2. In general, if a GCM shows a stronger weakening effect on $\mathrm{MJO}$ strength over the $\mathrm{MC}$, it tends to produce a stronger blocking effect on MJO propagation there.

The weakening effects on MJO strength and blocking effects on MJO propagation in the observation and GCMs are well demonstrated in the composite 

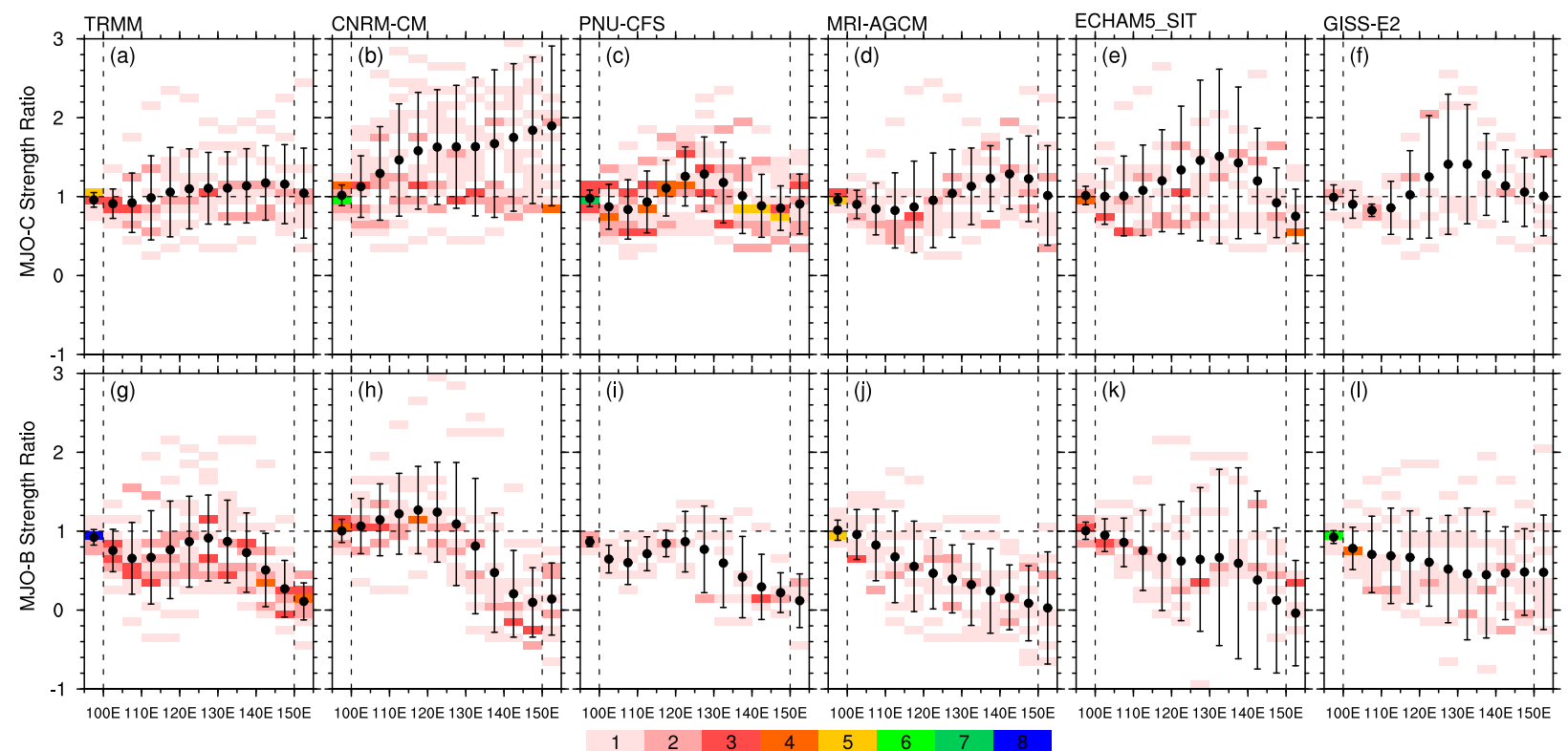

FIG. 6. Probability distribution of the ratio of tracked MJO strength to its averaged strength over $90^{\circ}-100^{\circ} \mathrm{E}$ as a function of longitude for (top) MJO-C and (bottom) MJO-B during boreal winter in (from left to right) TRMM, CNRM-CM, PNU-CFS, MRI-AGCM, ECHAM5-SIT, and GISS-E2. The width of the bin is $5^{\circ}$ and colors indicate the number of events. Dots are the means, and vertical whiskers mark one standard deviation.

time-longitude diagrams of precipitation anomalies (Fig. 7). The eastward-propagation speed of MJO in most GCMs has been found to be much faster than that in the observation in previous studies (Slingo et al. 1996;
Zhang 2005), but in our composite it is slightly slower than that in the observation. There are two possible reasons for the slower propagation speed in the GCMs. One is the improvement of models to better represent
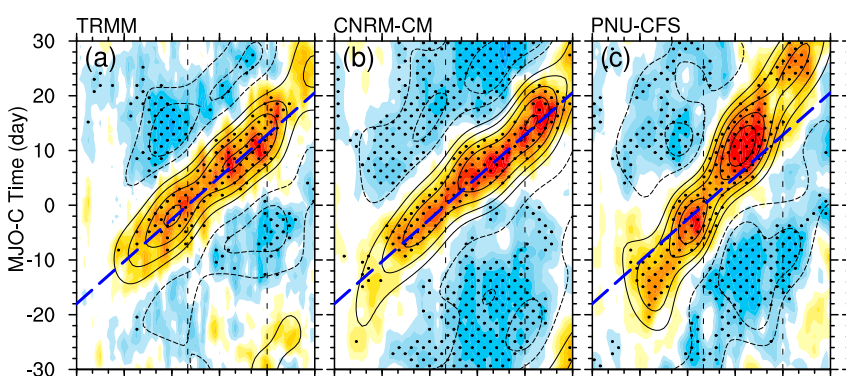

MRI-AGCM

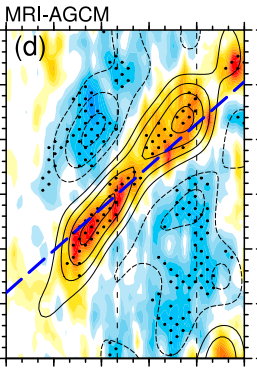

ECHAM5_SIT
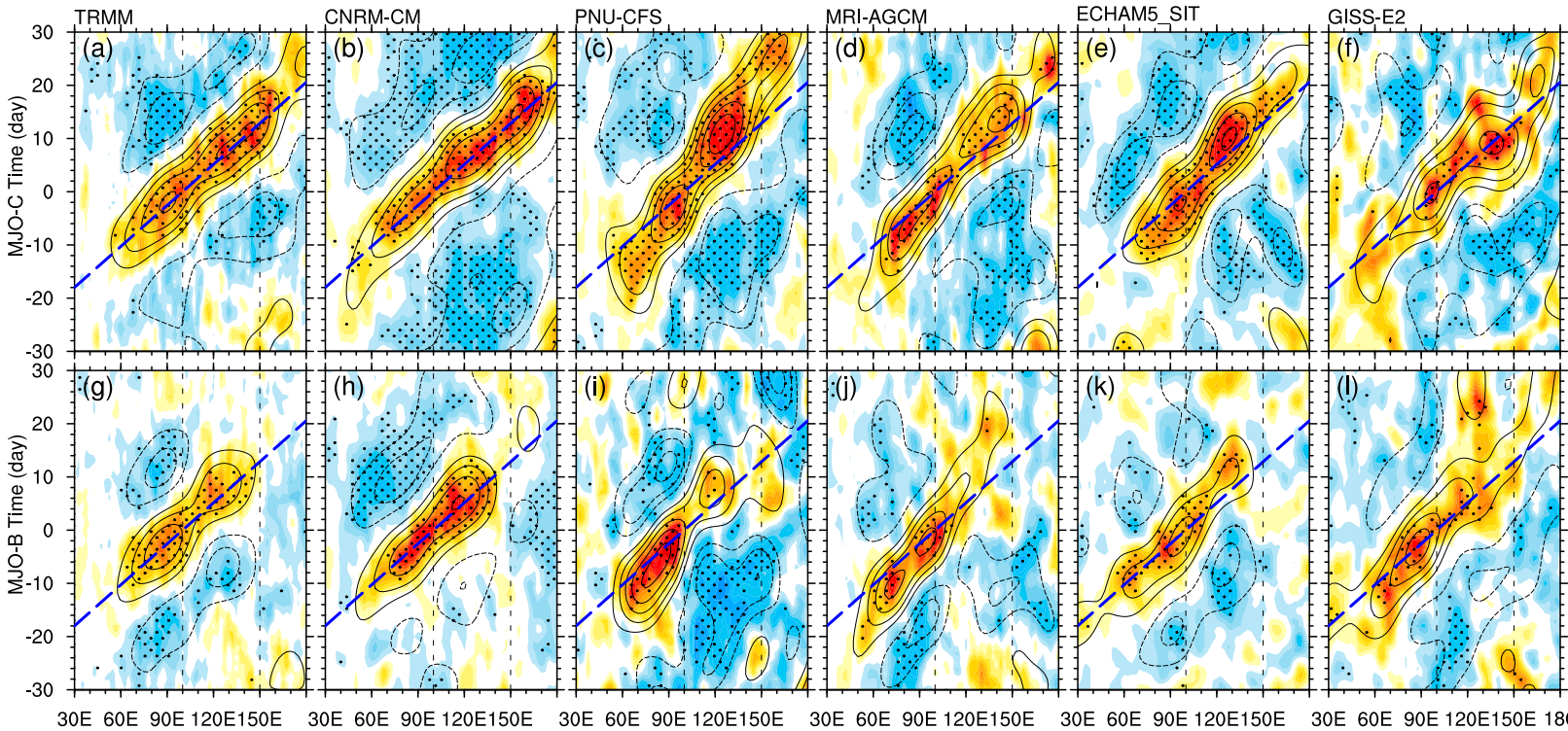

$30 \mathrm{E}$ 60E 90E 120E150E

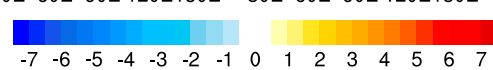

FIG. 7. Time-longitude diagrams of composites of 5 day running mean (color, $\mathrm{mm} \mathrm{day}^{-1}$ ) and intraseasonal filtered (contour, interval is $1 \mathrm{~mm} \mathrm{day}^{-1}$ ) precipitation anomalies of tracked MJO averaged over $10^{\circ} \mathrm{S}-10^{\circ} \mathrm{N}$ for (top) MJO-C and (bottom) MJO-B during boreal winter in (from left to right) TRMM, CNRM-CM, PNU-CFS, MRI-AGCM, ECHAM5-SIT, and GISS-E2. Time 0 is when an MJO track crosses $100^{\circ} \mathrm{E}$. The dashed straight lines mark the $5 \mathrm{~m} \mathrm{~s}^{-1}$ eastward propagation speed, and the dashed vertical lines marks the west and east boundary of the MC. Results significant at the $95 \%$ confidence level are stippled. 
the MJO dynamics. The other is the impact of faster eastward-propagating convection coupled Kelvin waves on composited speed is minimized by the MJO tracking method, while its impact on the regressed speed could not be eliminated by commonly used statistical methods. Both MJO-B and MJO-C in the observation and GCMs propagate eastward from the Indian Ocean to the MC with comparable amplitudes, which substantially decrease immediately afterward (passing $100^{\circ} \mathrm{E}$ ) except for CNRM-CM. The strength of MJO-B events never recovers, and they vanish over the MC, while the amplitude of MJO-C events almost fully recovers over the eastern MC in the observation and even increases in some GCMs (Figs. 7c-f).

The blocking effect on MJO propagation by the MC is very different among the GCMs, and its value varies from 0.22 to 1 during boreal winter (Fig. 5). In some GCMs, all MJO events vanish over the MC and never reach the western Pacific. If a model shows a stronger weakening effect on MJO strength over the MC, it tends to produce stronger blocking effect on MJO propagation over the MC. The barrier effect on MJO propagation by the MC is exaggerated in most GCMs; however, there are a few GCMs that produce weaker ones.

The horizontal resolutions of the GCMs in this study are too coarse to accurately depict the complex land-sea distribution and topography of the MC; therefore, simulated precipitation and the lower-tropospheric circulations in GCMs are different from the observation. The coarse resolutions of GCMs can deteriorate MJO simulations because they cannot reproduce well convection in the tropics, especially over the MC, while they can diminish the distortion effect on the lower-tropospheric circulation that is essential for MJO propagation because of the smoothed topography over the MC. They are unable to quantitatively evaluate the impacts of horizontal resolutions on the MJO barrier effect for each individual MJOTF/GASS GCM in the current study. Therefore, explaining why some GCMs produce weaker or stronger barrier effects than the observation is beyond the scope of this study. We only intend to explore the possible reasons why certain MJO events could overcome the barrier effect and propagate through the MC and others fail in GCMs, and whether their mechanisms are the same as the observation.

\section{c. MJO-C and MJO-B comparisons}

The overall amplitudes of the tracked MJO are different among GCMs (Fig. 7). To treat each GCM equally, normalization is applied to the composites from each GCM before calculating the multimodel composite. The composites for each individual GCM are generated first, and the amplitudes of MJO convection when entering the $\mathrm{MC}$ are used for normalization for each GCM. It was calculated as the mean composite intraseasonal filtered precipitation anomalies averaged over $10^{\circ} \mathrm{S}-10^{\circ} \mathrm{N}, 95^{\circ}-105^{\circ} \mathrm{E}$ for all tracked $\mathrm{MJO}$ events (both MJO-B and MJO-C) at day 0 when MJO tracks crosses $100^{\circ} \mathrm{E}$ (Fig. 7). The multimodel composite is the mean of the aforementioned normalized composite from each GCM.

The multimodel composited eastward propagation of anomalous precipitation, zonal wind, diabatic heating, and specific humidity at $850 \mathrm{hPa}$, and moisture flux convergence at $925 \mathrm{hPa}$ are shown in Fig. 8. The eastward-propagating anomalous zonal wind, diabatic heating, moisture, and moisture flux convergence do not show an obvious difference between MJO-C and MJO-B until an MJO convection center reaches the central MC $\left(130^{\circ} \mathrm{E}\right)$. From there, the amplitude of anomalous easterly wind, diabatic heating, and moisture at $850 \mathrm{hPa}$, and moisture flux convergence at $925 \mathrm{hPa}$ ahead of the MJO convection center, along with the positive precipitation anomalies, start to decrease in MJO-B.

Both MJO-C and MJO-B show comparable vertical and horizontal structures in terms of large-scale circulations, moisture, and diabatic heating when they enter the $\mathrm{MC}$ around $100^{\circ} \mathrm{E}$. An obvious westward tilt was identified in the vertical structure of moisture, with adequate moisture accumulating in the lower troposphere ahead of the MJO convection center (Figs. 9a,b). The amplitude of lower-tropospheric diabatic heating ahead of the MJO convection center is almost the same in MJO-C and MJO-B. The FWC in MJO-C and MJO-B are closed and almost identical (Figs. 9a,b). The horizontal structure of their anomalous precipitation and lower-tropospheric moisture show a similar swallowtail pattern pointed by Zhang and Ling (2012), but the lower-tropospheric easterly anomalies ahead of the MJO convection center are slightly stronger in MJO-C than MJO-B (Figs. 10a,b). The differences in the structures between MJO-C and MJO-B become distinct when their convection centers reach the central MC $\left(130^{\circ} \mathrm{E}\right)$ (Figs. 9c,d). The lower-tropospheric moisture and diabatic heating ahead of the MJO convection center become very weak in MJO-B (Fig. 9d). Both the swallowtail-pattern precipitation anomaly and the anomalous FWC in MJO-B disappear (Figs. 9d and 10d), while they remain in MJO-C (Figs. 9c and 10c).

Most previous studies examined the mechanism of eastward propagation of the MJO using column-integrated MSE or moisture; however, this method could ignore the westward-tilted thermal and dynamical structures of the MJO, and then underestimates the role of lowertropospheric moisture and diabatic heating ahead of the MJO convection center shown in Fig. 9. To 

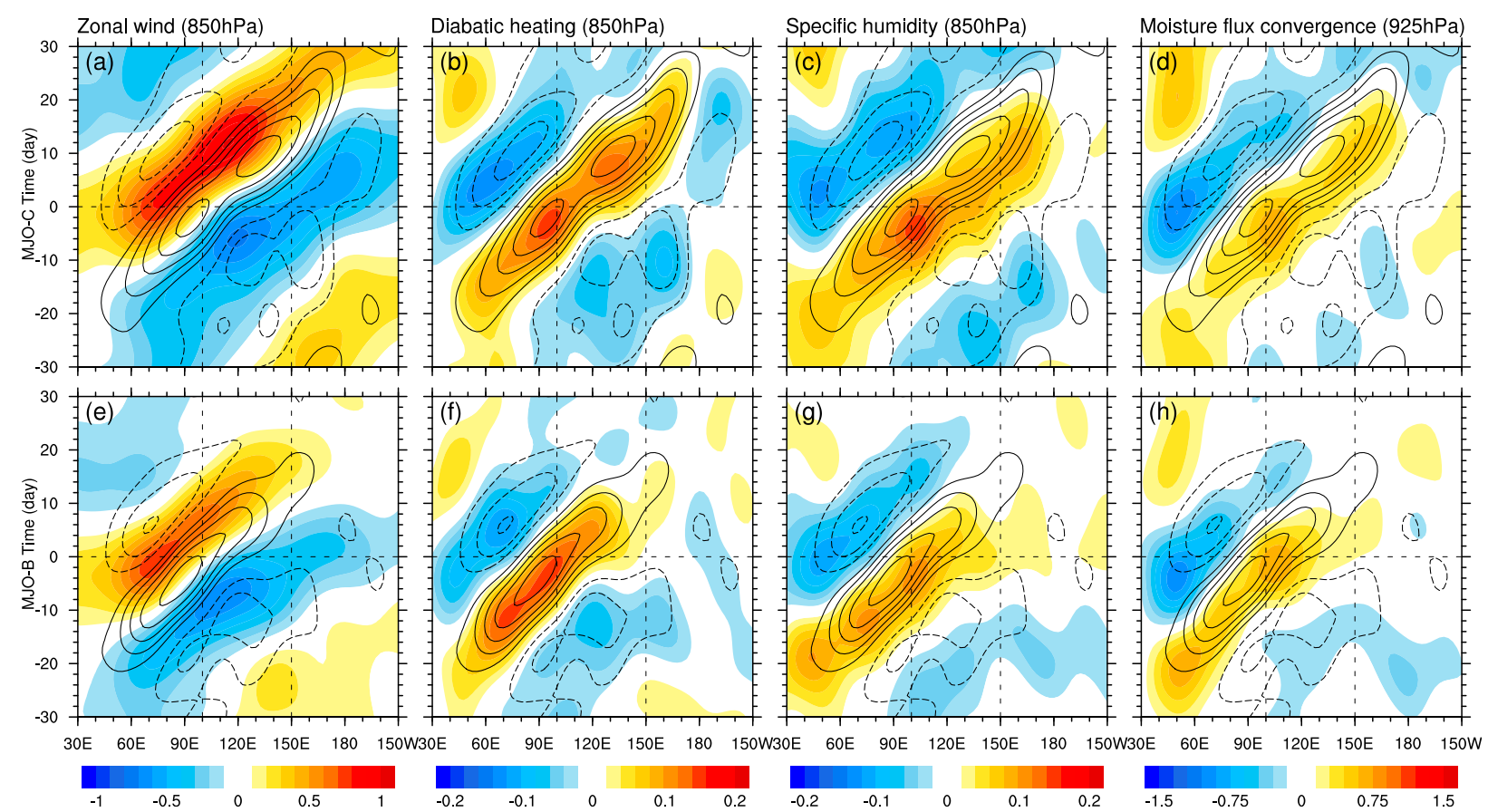

FIG. 8. Time-longitude diagrams of multimodel composites of intraseasonal filtered normalized anomalous precipitation (contour, interval is 0.2 ) and (from left to right) zonal wind at $850 \mathrm{hPa}\left[\mathrm{m} \mathrm{s}^{-1}\left(\mathrm{~mm} \mathrm{day}^{-1}\right)^{-1}\right]$, diabatic heating at $850 \mathrm{hPa}\left[\mathrm{K}\left(\mathrm{mm} \mathrm{day}^{-1}\right)^{-1}\right]$, $\mathrm{specific}^{-1}$ humidity at $850 \mathrm{hPa}\left[\mathrm{g} \mathrm{kg}^{-1}\left(\mathrm{~mm} \mathrm{day}^{-1}\right)^{-1}\right]$, and moisture flux convergence at $925 \mathrm{hPa}\left[10^{-6} \mathrm{~g} \mathrm{~kg}^{-1} \mathrm{~s}^{-1}\left(\mathrm{~mm} \mathrm{day}^{-1}\right)^{-1}\right]$ of tracked MJO averaged over $10^{\circ} \mathrm{S}-10^{\circ} \mathrm{N}$ for (top) MJO-B and (bottom) MJO-C during boreal winter. Time 0 is when an MJO track crosses $100^{\circ} \mathrm{E}$. The dashed vertical lines mark the west and east boundaries of the MC.

highlight the role of the lower troposphere, a massweighted average over $1000-700 \mathrm{hPa}$ is used for diagnostic. The zonal distributions of lower-tropospheric diabatic heating, moisture, and moisture flux convergence averaged over $10^{\circ} \mathrm{S}-10^{\circ} \mathrm{N}$ are almost the same for MJO-C and MJO-B when the MJO convection center is over $100^{\circ} \mathrm{E}$ (Figs. 11a,c,e), but their amplitude ahead of the MJO convection is much weaker in MJO-B when an $\mathrm{MJO}$ convection center crosses $130^{\circ} \mathrm{E}$ (Figs. $11 \mathrm{~b}, \mathrm{~d}, \mathrm{f}$ ). The mean lower-tropospheric diabatic heating, moisture, and moisture flux convergence within a $20^{\circ}$ window with its center $30^{\circ}$ ahead of the MJO convection center (blue strips in Fig. 11) are further evaluated for individual selected GCMs and the observation. In the observation, positive diabatic heating, moisture, and moisture flux convergence anomalies in the lower troposphere lead MJO convection for both MJO-C and MJO-B, and their mean values are larger in $\mathrm{MJO}-\mathrm{C}$ when an $\mathrm{MJO}$ enters the MC (black dots in Figs. 12a-c). Most GCMs can capture the observed differences between MJO-C and MJO-B, but the differences are not significant. However, in MRI-AGCM and PNU-CFS, the amplitudes of lowertropospheric diabatic heating and moisture are larger in MJO-B than those in MJO-C (Figs. 12a,b). The differences in the lower troposphere between MJO-C and MJO-B become significant when the MJO convection moves to the central MC (Figs. 12d-f) in most models except PNUCFS. PNU-CFS shows larger lower-tropospheric diabatic heating and moisture flux convergence in MJO-B than MJO-C, indicating that the three-dimensional structure of MJO in PNU-CFS may not be the same with the other four GCMs and observation (Fig. 12f). For the rest of the GCMs (CNRM-CM, MRI-AGCM, ECHAM5-SIT, and GISS-E2), the diabatic heating, moisture, and moisture flux convergence anomalies in the lower troposphere ahead of the MJO convection center are much larger in MJO-C than MJO-B, which is the same as the observation, and it may be the reason why MJO-C could continuously propagate eastward into the western Pacific.

The lower-tropospheric premoistening ahead of the MJO convection center is suggested to be important for MJO propagation (Andersen and Kuang 2012; Ling et al. 2013; Zhao et al. 2013; Li 2014; Hsu et al. 2014). The moisture budget analysis is applied to the lower troposphere ahead of the MJO convection center when it is over the central $\mathrm{MC}\left(130^{\circ} \mathrm{E}\right)$ following Yanai et al. (1973):

$$
\frac{\partial q}{\partial t}=-\frac{\partial u q}{\partial x}-\frac{\partial v q}{\partial y}-\frac{\partial \omega q}{\partial p}-\frac{Q_{2}}{L}
$$

where $u, v$, and $\omega$ are three-dimensional wind components; $q$ is the specific humidity; and $L$ is the latent heat 

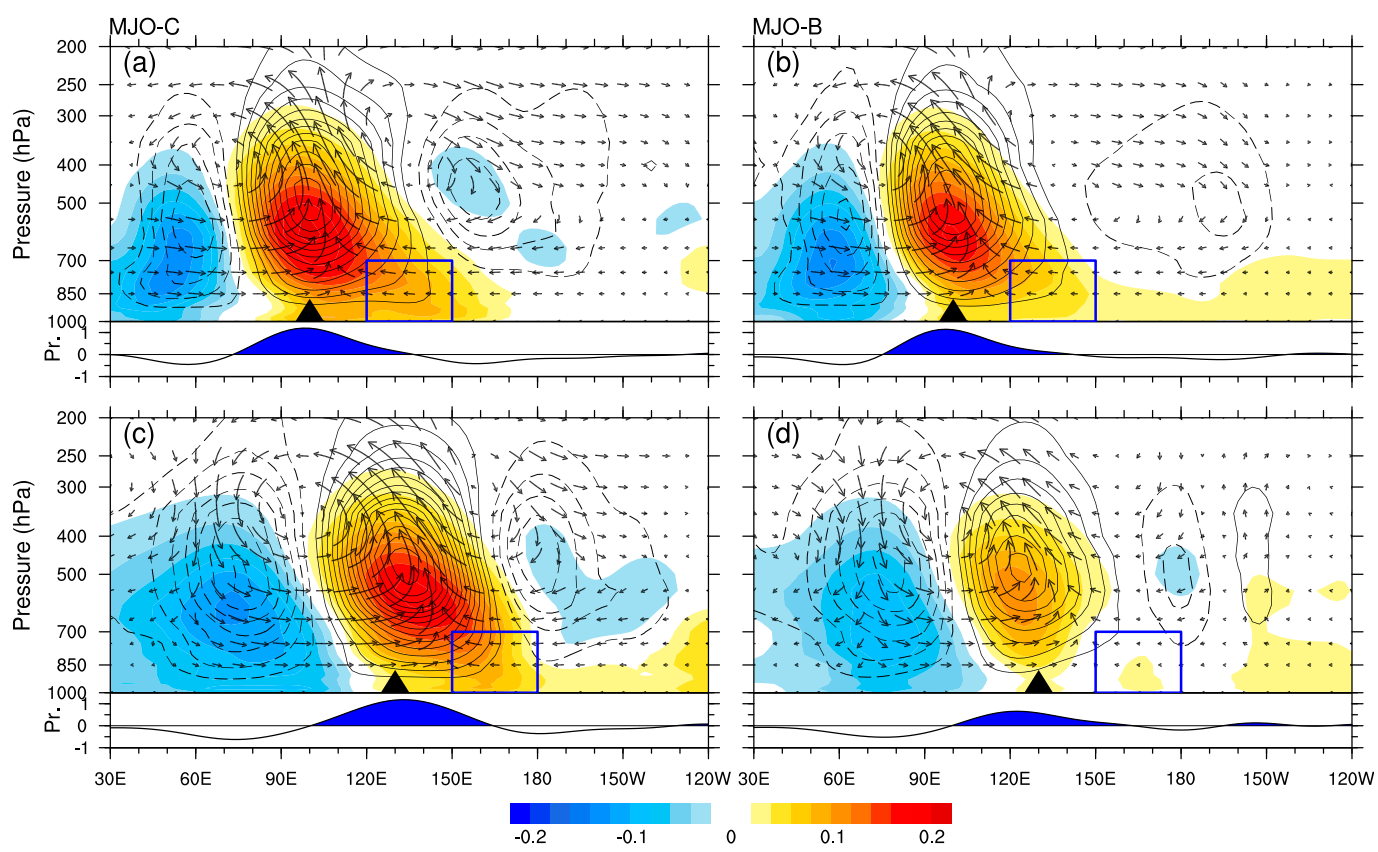

FIG. 9. Multimodel composites of zonal-vertical distributions of normalized anomalous wind vectors $(\mathbf{u}, \mathbf{w})$ overlaid with diabatic heating [contours, interval is $0.05 \mathrm{~K} \mathrm{day}^{-1}\left(\mathrm{~mm} \mathrm{day}^{-1}\right)^{-1}$ ] and specific humidity [ $\mathrm{g} \mathrm{kg}^{-1}$ $\left(\mathrm{mm} \mathrm{day}^{-1}\right)^{-1}$ ], as well as correspondingly precipitation (curves), all averaged over $10^{\circ} \mathrm{S}-10^{\circ} \mathrm{N}$, for (left) MJO-C and (right) $\mathrm{MJO}-\mathrm{B}$ when their tracks pass (top) $100^{\circ} \mathrm{E}$ and (bottom) $130^{\circ} \mathrm{E}$ marked by solid triangles. Vertical velocities are scaled by a factor of 250 to make them visible.

of condensation. In general, total moisture flux convergence is the sum of the first three terms on right-hand side of the equation, which provides a large-scale source of moisture, and $Q_{2}$ represents moisture removed from the atmosphere by precipitation and evaporation through microphysical processes.

The zonal structure of the zonal, meridional, and vertical components of moisture flux convergence when the MJO convection center is over the central MC $\left(130^{\circ} \mathrm{E}\right)$ are shown in Fig. 13a. The zonal and vertical components are the dominant terms. The zonal component transports moisture from the east to the contiguous area of the MJO convection center, and the vertical component transports moisture from the boundary layer to the free atmosphere in the contiguous area of the MJO convection and from the free atmosphere to the boundary layer by the subsidence branch of the FWC (Fig. 9c) within the LSC. A further diagnostic indicates
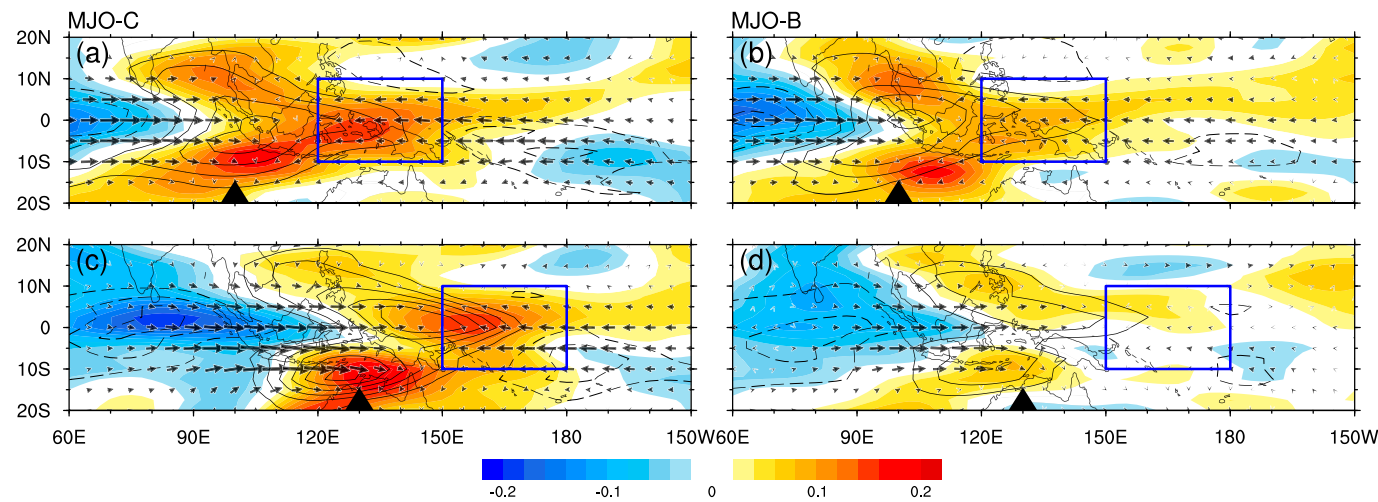

FIG. 10. Horizontal distributions of multimodel composites of anomalous horizontal wind vector $\left[\mathrm{m} \mathrm{s}^{-1}\right.$ $\left(\mathrm{mm} \mathrm{day}^{-1}\right)^{-1}$ ] and precipitation (contours, interval is 0.3$)$ overlaid with specific humidity $\left[\mathrm{g} \mathrm{kg}^{-1}\left(\mathrm{~mm} \mathrm{day}^{-1}\right)^{-1}\right]$ at $850 \mathrm{hPa}$ for (left) MJO-C and (right) MJO-B when their tracks pass (top) $100^{\circ} \mathrm{E}$ and (bottom) $130^{\circ} \mathrm{E}$ marked by solid triangles. 

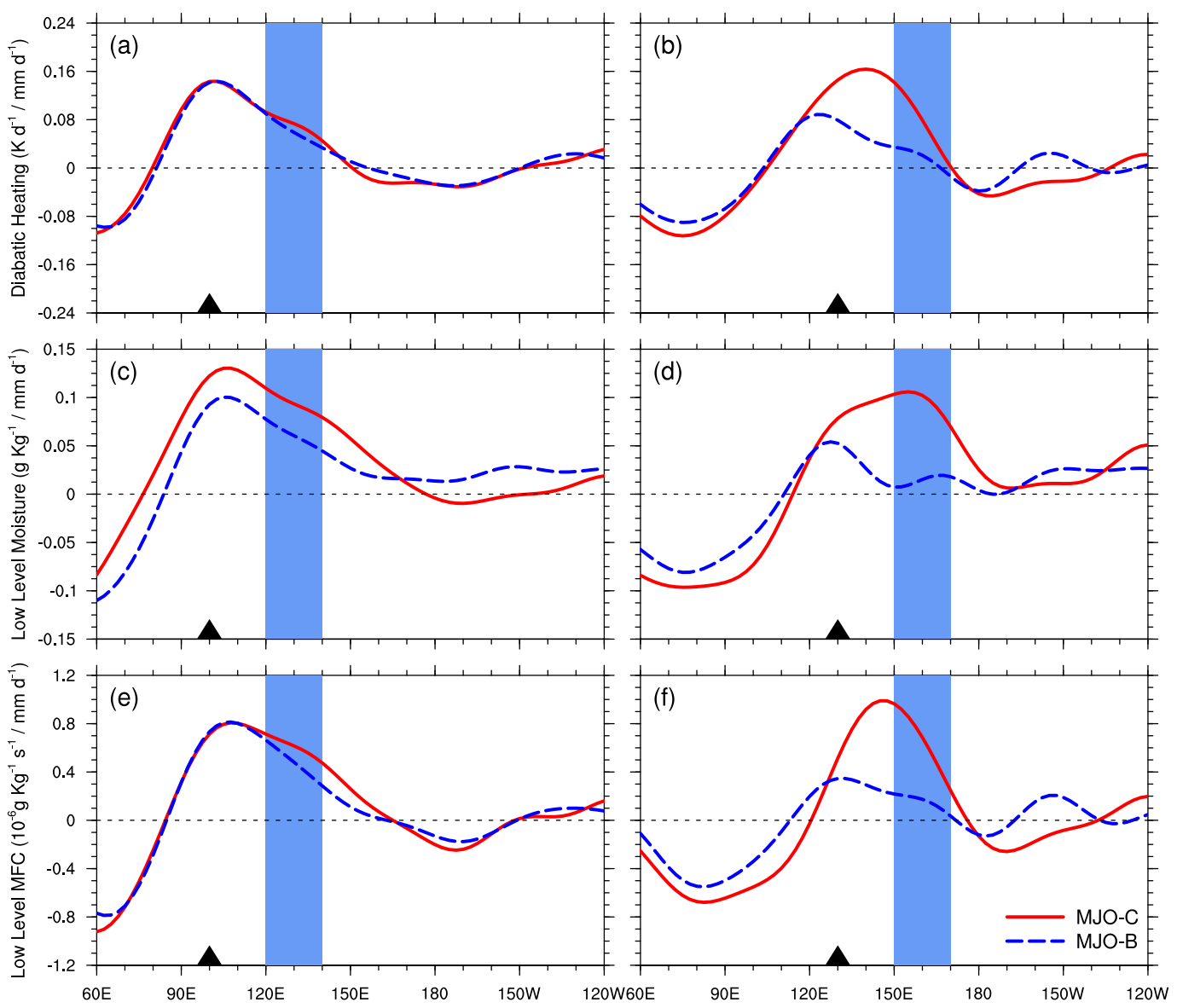

FIG. 11. Zonal distributions of multimodel composites of normalized anomalous (a),(b) diabatic heating $\left[\mathrm{K} \mathrm{day}^{-1}\left(\mathrm{~mm} \mathrm{day}^{-1}\right)^{-1}\right]$, (c),(d) specific humidity $\left[\mathrm{g} \mathrm{kg}^{-1}\left(\mathrm{~mm} \mathrm{day}^{-1}\right)^{-1}\right]$, and (e),(f) moisture flux convergence $\left[10^{-6} \mathrm{~g} \mathrm{~kg}^{-1} \mathrm{~s}^{-1}\left(\mathrm{~mm} \mathrm{day}^{-1}\right)^{-1}\right]$, all weighted averaged over $1000-700 \mathrm{hPa}$ and $10^{\circ} \mathrm{S}-10^{\circ} \mathrm{N}$, for $\mathrm{MJO}-\mathrm{C}$ (red solid lines) and MJO-B (blue dashed lines) when their tracks pass (left) $100^{\circ} \mathrm{E}$ and (right) $130^{\circ} \mathrm{E}$ marked by solid triangles.

that the vertical advection $(-\omega \partial q / \partial p)$ term is the dominant term for premoistening the lower troposphere ahead of the MJO convection center (Fig. 13b), which is consistent with Sobel et al. (2014). Based on the continuity equation, the total contribution of the three divergent terms $(-q \partial u / \partial x-q \partial v / \partial y-q \partial \omega / \partial p)$ in the moisture flux convergence is zero in premoistening the lower troposphere; however, their role is to moisten the free atmosphere above the contiguous area of MJO convection center by transporting moisture from the boundary layer east of $170^{\circ} \mathrm{E}$ to favor the development of deep convection. Furthermore, the vertical velocity, which is important in premoistening the lower troposphere, is mainly attributed to the zonal gradient of the easterly anomalies within the boundary layer according to the continuity law and the diabatic heating released in the lower troposphere there (Li et al. 2009). Therefore, the vertical advection $(-\omega \partial q / \partial p)$ and zonal divergent $(-q \partial u / \partial x)$ terms are further evaluated through the scale decomposition analysis.

Following Hsu and Li (2012), the specific humidity, zonal velocity, and vertical velocity are decomposed into three components, the low-frequency background state (LFBS, with a period longer than 100 days), the MJO (20-100 day), and the high-frequency (with a period shorter than 20 days) components:

$$
q=\bar{q}+q^{\prime}+q^{*} ; \quad u=\bar{u}+u^{\prime}+u^{*} ; \quad \omega=\bar{\omega}+\omega^{\prime}+\omega^{*},
$$

where the bar, prime, and asterisk denote the LFBS, MJO, and high-frequency components, respectively. The results show that the zonal divergent term is mainly attributed to the LFBS specific humidity and the zonal gradient of the MJO zonal wind $\left(-\bar{q} \partial u^{\prime} / \partial x\right)$. The vertical advection term is mainly attributed to the advection of LFBS specific humidity by the MJO vertical velocity 

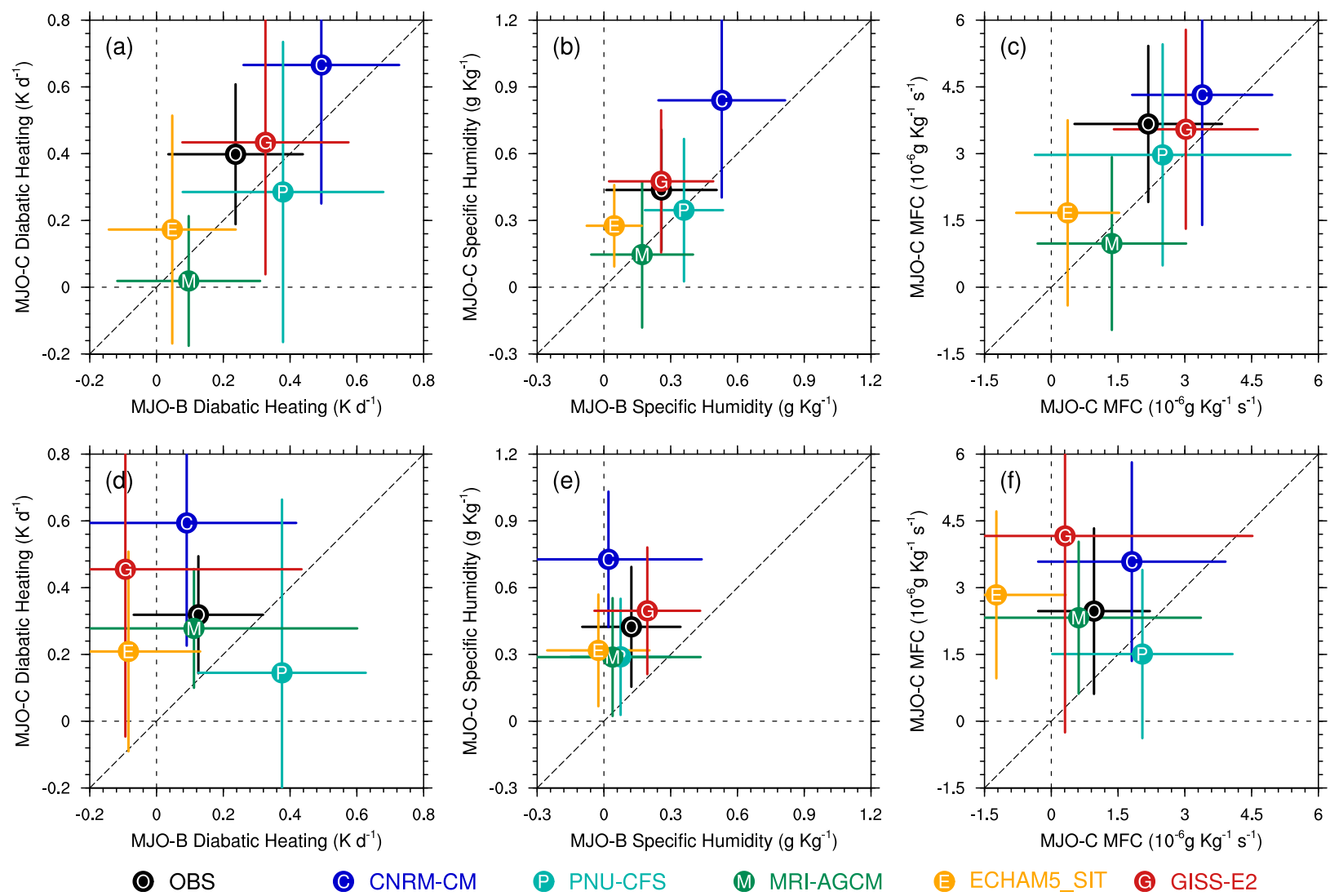

FIG. 12. Scatter diagrams of composited anomalous (a),(d) diabatic heating $\left(\mathrm{K} \mathrm{day}^{-1}\right)$, (b),(e) specific humidity ( $\left.\mathrm{g} \mathrm{kg}^{-1}\right)$, and (c),(f) moisture flux convergence $\left(10^{-6} \mathrm{~g} \mathrm{~kg}^{-1} \mathrm{~s}^{-1}\right)$, all weighted averaged over $1000-700 \mathrm{hPa}, 10^{\circ} \mathrm{S}-10^{\circ} \mathrm{N}$, and $150^{\circ}-170^{\circ} \mathrm{E}$ for all tracked MJO-C events vs MJO-B events in the observation and GCMs when their tracks pass (top) $100^{\circ} \mathrm{E}$ and (bottom) $130^{\circ} \mathrm{E}$. The vertical and horizontal whiskers mark one standard deviation.

$\left(-\omega^{\prime} \partial \bar{q} / \partial p\right)$. The combined efforts of LFBS specific humidity and the MJO zonal and vertical circulation play important roles in premoistening the lower troposphere ahead of the MJO convection center. Their differences between MJO-C and MJO-B may be the reasons for the different propagation characteristics between MJO-C and MJO-B over the MC.

The total vertical moisture advection $(-\omega \partial q / \partial p)$ and its dominant term $\left(-\omega^{\prime} \partial \bar{q} / \partial p\right)$ ahead of MJO convection center averaged over $150^{\circ}-170^{\circ} \mathrm{E}$ for the observation and selected GCMs are shown in Figs. 14a and 14b. Their values are almost identical to the total moisture flux convergence shown in Fig. 12f. All GCMs can capture the role the of the vertical moisture advection in premoistening the lower troposphere in MJO-C, except for PNU-CFS. The results emphasize that the difference in lower-tropospheric MJO vertical velocity ahead of the MJO convection center and the zonal gradient of the easterly anomalies in the lower troposphere (Fig. 14d) between MJO-C and MJO-B may be the reason why MJO-C can continue to propagate eastward through the
MC. The difference in mean easterly anomalies ahead of MJO convection center between MJO-C and MJO-B is not significant in GCMs (Fig. 14c).

Wang and Lee (2017) defined the Rossby-Kelvin (R-K) intensity index, which is the ratio of the maximum westerly anomaly versus the minimum easterly anomaly at $850 \mathrm{hPa}$ to quantify the zonal asymmetry of MJO circulation. They suggested a GCM that simulated stronger easterly ahead of MJO convection center could reproduce better eastward propagation of MJO. Chen and Wang (2018) found an obvious LSC over the MC and the western Pacific when the MJO convection is over the Indian Ocean, and such LSC could help MJO to propagate through the MC in the observation.

The possible role of the R-K index in the eastward propagation of MJO was reevaluated using the MJO tracking method in the study. The R-K index for each individual GCM was not retrieved from the composited zonal structure of zonal wind following Wang and Lee (2017). Instead, the R-K index for each individual MJO event was retrieved separately as the ratio of the 

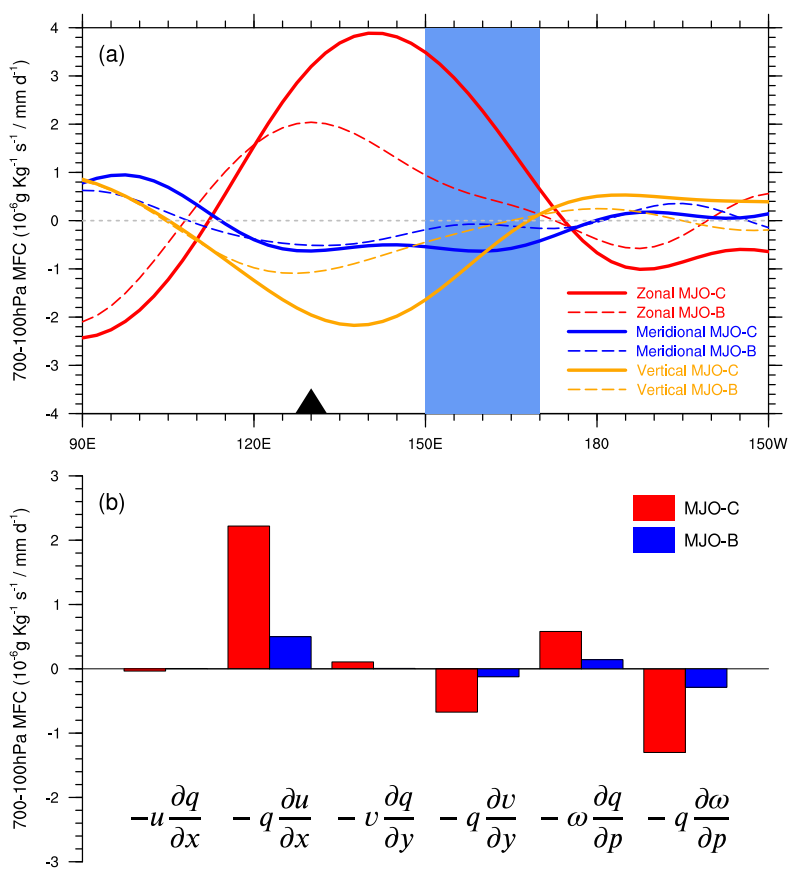

FIG. 13. (a) Zonal distributions of multimodel composites of normalized anomalous zonal, meridional, and vertical components of moisture flux convergence $\left[10^{-6} \mathrm{~g} \mathrm{~kg}^{-1} \mathrm{~s}^{-1}\left(\mathrm{~mm} \mathrm{day}^{-1}\right)^{-1}\right]$ weighted averaged over $1000-700 \mathrm{hPa}$ and $10^{\circ} \mathrm{S}-10^{\circ} \mathrm{N}$, for MJO-C and MJO-B when their tracks pass $130^{\circ} \mathrm{E}$. (b) Multimodel composites of individual terms of normalized anomalous moisture flux convergence $\left(10^{-6} \mathrm{~g} \mathrm{~kg}^{-1} \mathrm{~s}^{-1}\right)$ weighted averaged over 1000$700 \mathrm{hPa}, 10^{\circ} \mathrm{S}-10^{\circ} \mathrm{N}$, and $150^{\circ}-170^{\circ} \mathrm{E}$ for all tracked MJO-C and $\mathrm{MJO}-\mathrm{B}$ events when their tracks pass $130^{\circ} \mathrm{E}$.

minimum of easterly anomaly versus the maximum of westerly anomaly. During the eastward propagation of the MJO from $100^{\circ}$ to $130^{\circ} \mathrm{E}$ (Fig. 15), the amplitudes of the R-K index drop obviously in most GCMs, implying the weakening of the zonal asymmetry of the large-scale MJO circulation during its eastward propagation (Figs. 15c,d). There is no obvious difference in the $\mathrm{R}-\mathrm{K}$ index between MJO-C and MJO-B for GCMs when MJO convection is over the western MC (around $100^{\circ}$ and $130^{\circ} \mathrm{E}$ ). Only CNRM-CM tends to show a larger amplitude of the R-K index in MJO-C than MJO-B, while other GCMs produce comparable amplitudes of the R-K index for both MJO-C and MJO-B. The zonal gradient of zonal wind (Figs. 15e,f) here is calculated as the difference between minimum easterly and maximum westerly (Figs. 15a,b) divided by their zonal distance. No distinct difference in zonal gradient of zonal wind is shown between MJO-C and MJO-B when $\mathrm{MJO}$ entering the MC (Fig. 15e), but their difference becomes obvious when MJO propagates to the central MC (Fig. 15f). The results are generally consistent with Fig. 14d, which only depicts the zonal gradient of zonal wind within a small range. The amplitude of the LSC in this study is measured by the minimum easterly wind at $850 \mathrm{hPa}$ ahead of the MJO convection center. The difference in the amplitude between MJO-C and MJO-B in the observation becomes obvious when the MJO enters the MC, which is consistent with Chen and Wang (2018). Such differences are distinct only in CNRM-CM and GISS-E2. When the MJO reaches the central MC, the amplitudes of the minimum easterly anomalies in MJO-C are generally larger than those in MJO-B. The larger amplitude of the LSC in MJO-C could induce a stronger zonal gradient of zonal wind in the lower troposphere, and further lead to stronger moisture flux convergence ahead of the convection center of MJO-C through thermal and dynamic processes. However, both MJO-C and MJO-B show the obvious LSC with the closed FWC when their convection enters the MC (Figs. 9a,b), and the FWC in MJO-B disappears later. What happened to the FWC in MJO-B and the role of the MC in the evolution of the FWC need further examination to fully reveal the mechanism of the eastward propagation of MJO.

Ling et al. (2017) suggested that the background state in which a GCM could simulate an MJO event is different from that in which no MJO events were produced by the GCMs. The background state of the SST for each tracked MJO was defined as the mean of the SST anomaly from day -45 to 45 , with day 0 as the day when the MJO track passed $100^{\circ} \mathrm{E}$. In the observation, slightly warmer tropical SSTs (averaged over $10^{\circ} \mathrm{S}-10^{\circ} \mathrm{N}$ ) over the central and eastern Pacific were found for MJO-C (Fig. 15a), which could help the development of deep convection there and favor the eastward propagation of MJO. The relatively lower SST over the MC for MJO-C may be due to less solar radiation reaching the surface to warm the SST because of stronger convection for MJO-C over the $\mathrm{MC}$ and stronger evaporation effect underneath the MJO convection center in MJO-C that lasts longer over the MC. However, the SST over the central and eastern Pacific is slightly lower for MJO-C than that of MJO-B not only in coupled models (CNRM-CM and ECHAM5-SIT) but also in uncoupled models (MRIAGCM and GISS-E2) (Fig. 15b). These results suggested that the role of the air-sea coupling in the eastwardpropagation mechanism of MJO in certain GCMs needs further examination. For those GCMs, more effort should be made to improve the air-sea coupling to fully depict the dynamics and propagation characteristic of MJO.

One possible role of the diurnal cycle in the barrier effect on MJO propagation by the MC is through the competition between convection over land and water in the MC. It has been observed that when an MJO event moves through the MC, its signal in precipitation is 

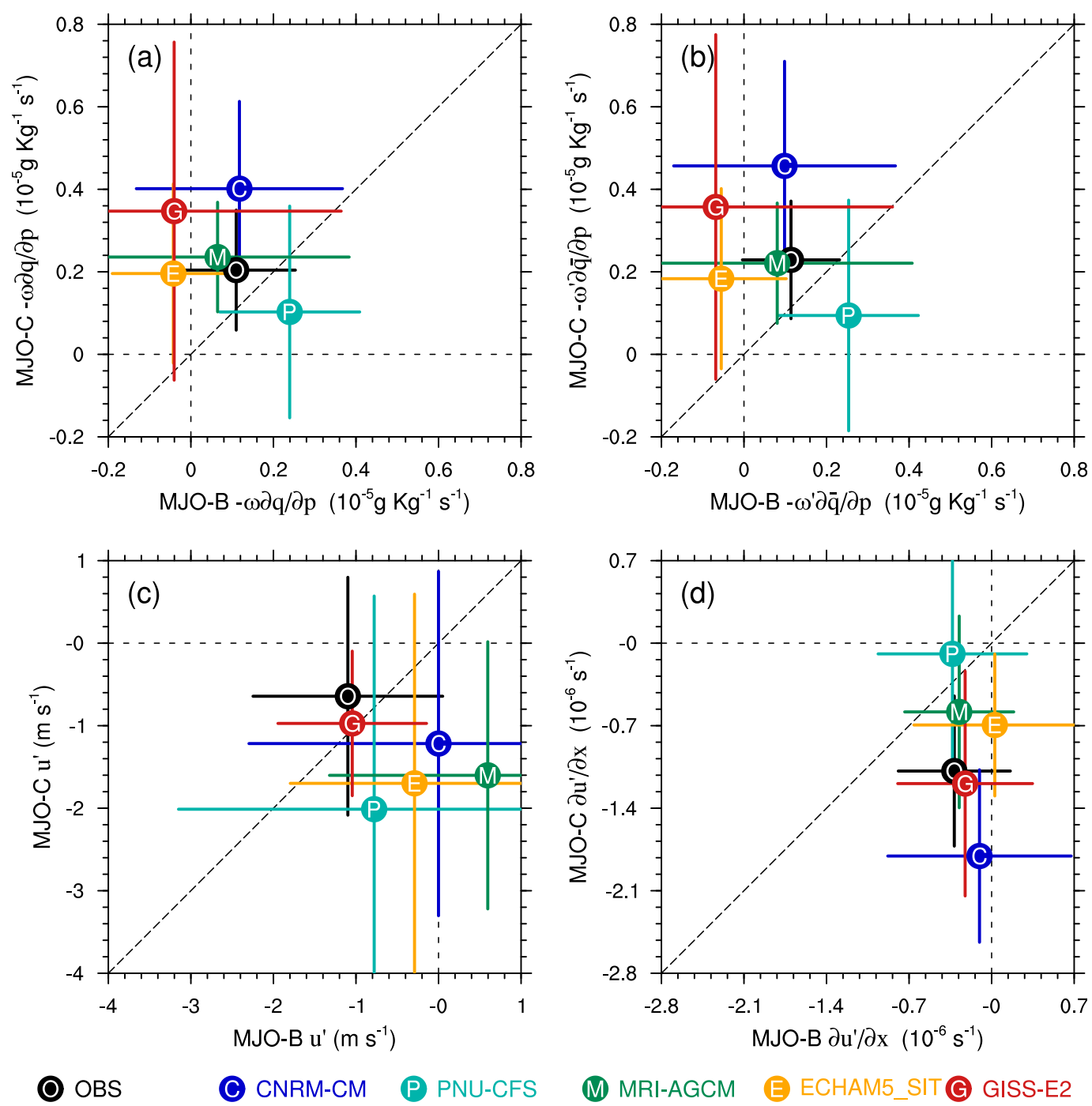

FIG. 14. Scatter diagrams of composited anomalous (a) moisture flux convergence $\left(10^{-5} \mathrm{~g} \mathrm{~kg}^{-1} \mathrm{~s}^{-1}\right)$ due to (a) total vertical velocity and specific humidity, and (b) MJO vertical velocity and low-frequency specific humidity all weighted averaged over $1000-700 \mathrm{hPa}, 10^{\circ} \mathrm{S}-10^{\circ} \mathrm{N}$, and $150^{\circ}-170^{\circ} \mathrm{E},(\mathrm{c}) \mathrm{MJO}$ zonal wind $\left(\mathrm{m} \mathrm{s}^{-1}\right)$, and (d) its zonal gradient $\left(10^{-6} \mathrm{~s}^{-1}\right)$ at $850 \mathrm{hPa}$ all averaged over $10^{\circ} \mathrm{S}-10^{\circ} \mathrm{N}, 150^{\circ}-170^{\circ} \mathrm{E}$ for all tracked MJO-C events vs MJO-B events in the observation and GCMs when their tracks pass $130^{\circ} \mathrm{E}$. The vertical and horizontal whiskers mark one standard deviation.

carried mainly by convection over water (Zhang and Ling 2017; Ling et al. 2019), which mainly comes from mesoscale convective systems (MCSs) sometimes organized into 2-day waves in the tropics (Chen et al. 1996). In the observation, the mean precipitation over water is larger than that over land when the MJO-C convection center is over the MC (red solid line in Fig. 16a), while the precipitation over water never becomes dominant for MJO-B (blue dashed line in Fig. 16a). Not only the horizontal resolution $\left(2.5^{\circ} \times\right.$ $\left.2.5^{\circ}\right)$ but also the temporal resolution (6 hourly) of the outputs from the GCMs are too coarse to evaluate the possible role of the diurnal cycle in the barrier effect on MJO propagation. Instead, only the averaged ratio of the mean precipitation over water versus that over land when the MJO convection is over the MC is evaluated for GCMs. Only CNRM-CM can capture the observed evolution of the precipitation of MJO over the MC during its eastward propagation. The remaining four models produce more precipitation over land than water for both MJO-C and MJO-B. The results may indicate the interactions between the diurnal cycle in convection and the MJO propagation are not well depicted in most current GCMs. 

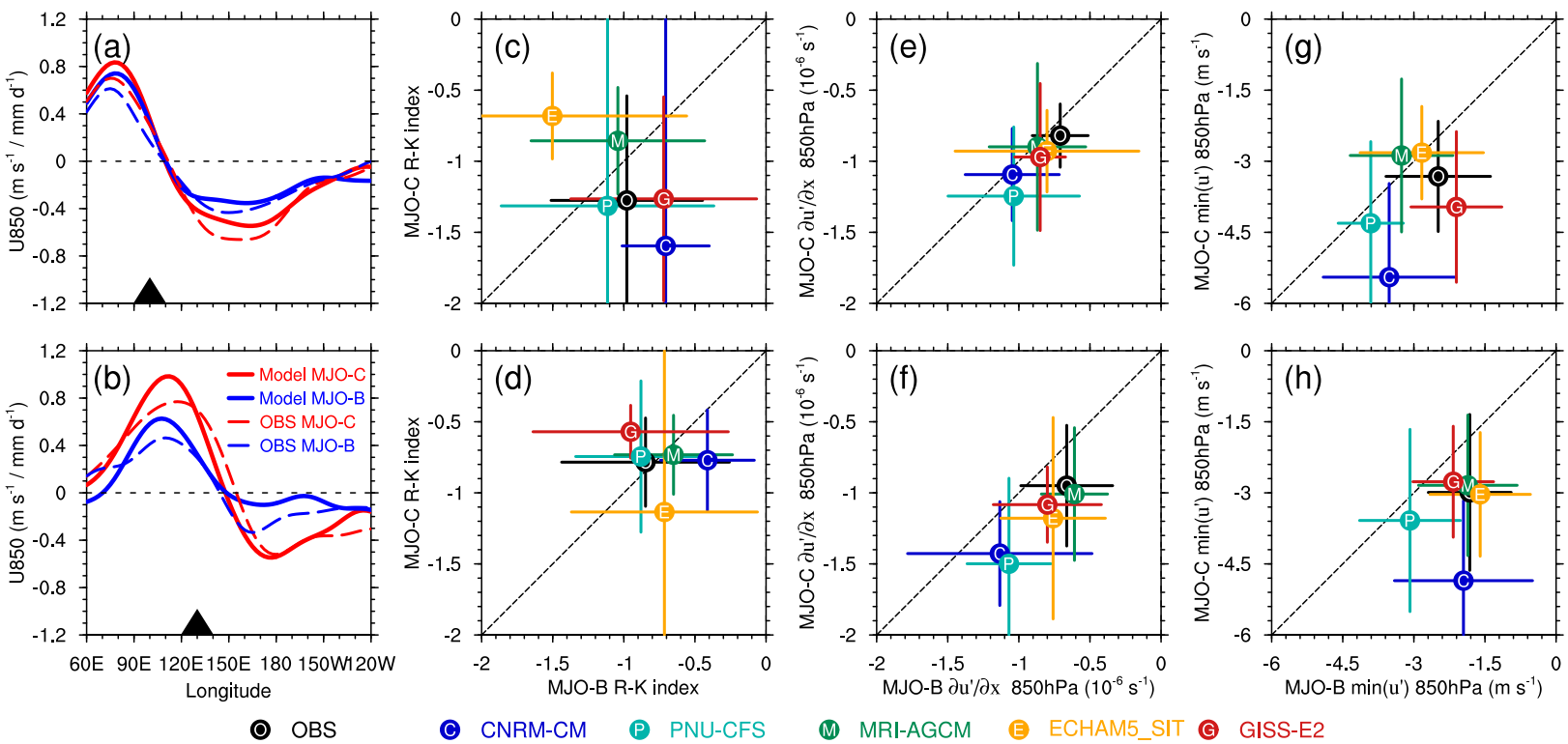

FIG. 15. Zonal distributions of composited anomalous zonal wind $\left(\mathrm{m} \mathrm{s}^{-1}\right)$ averaged over $10^{\circ} \mathrm{S}-10^{\circ} \mathrm{N}$ for MJO-C and MJO-B in observations and GCMs when their tracks pass (a) $100^{\circ} \mathrm{E}$ and (b) $130^{\circ} \mathrm{E}$. Scatter diagrams of composited (c),(d) R-K index intensities, (e),(f) zonal gradient of zonal wind anomalies, and (g),(h) minimum zonal wind anomalies in the tropics for all tracked MJO-C events vs MJO-B events in the observation and GCMs when their tracks pass (top) $100^{\circ} \mathrm{E}$ and (bottom) $130^{\circ} \mathrm{E}$. The vertical and horizontal whiskers mark one standard deviation.

\section{Summary and discussion}

In this study, the abilities of the $27 \mathrm{MJOTF} / \mathrm{GASS}$ GCMs to simulate MJO propagation were evaluated using an MJO tracking method. All GCMs underestimate the occurrence frequency of MJO events (Fig. 1). In more than $89 \%$ of GCMs, occurrence frequencies of the MJO are only less than half those in observation. Occurrence frequencies of tracked MJO events are related to other MJO simulation abilities of the GCMs during boreal winter. A GCM that produces a greater occurrence frequency of MJO events is likely to produce longer MJO propagation range, stronger strength, and farther east termination locations during boreal winter (Fig. 2).

The $\mathrm{MC}$ is the only one distinct termination location for MJO events simulated by most GCMs, whereas there are two in the observation (Fig. 4). The weakening
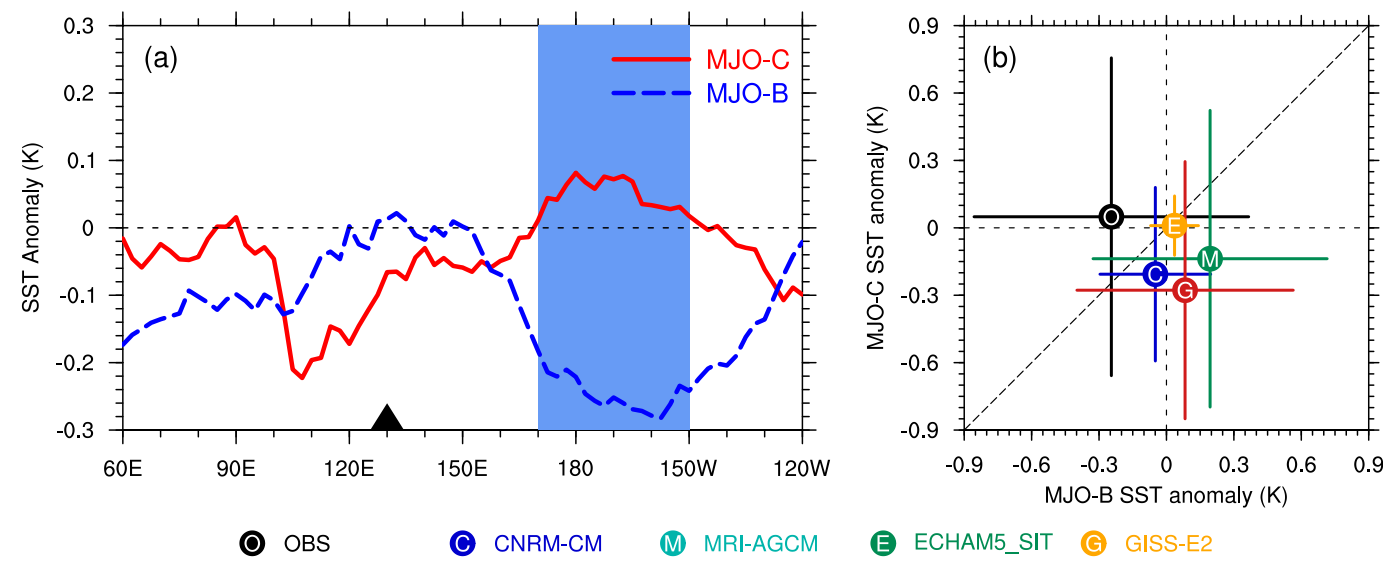

FIG. 16. (a) Zonal distributions of composited anomalous SST (K) averaged over $10^{\circ} \mathrm{S}-10^{\circ} \mathrm{N}$ for MJO-C and MJO-B in observations when their tracks pass $130^{\circ}$ E. (b) Scatter diagrams of composited anomalous SST $(\mathrm{K})$ averaged over $10^{\circ} \mathrm{S}-10^{\circ} \mathrm{N}, 170^{\circ} \mathrm{E}-150^{\circ} \mathrm{W}$ for all tracked MJO-C events vs MJO-B events in the observation and GCMs when their tracks pass $130^{\circ} \mathrm{E}$. The vertical and horizontal whiskers mark one standard deviation. 

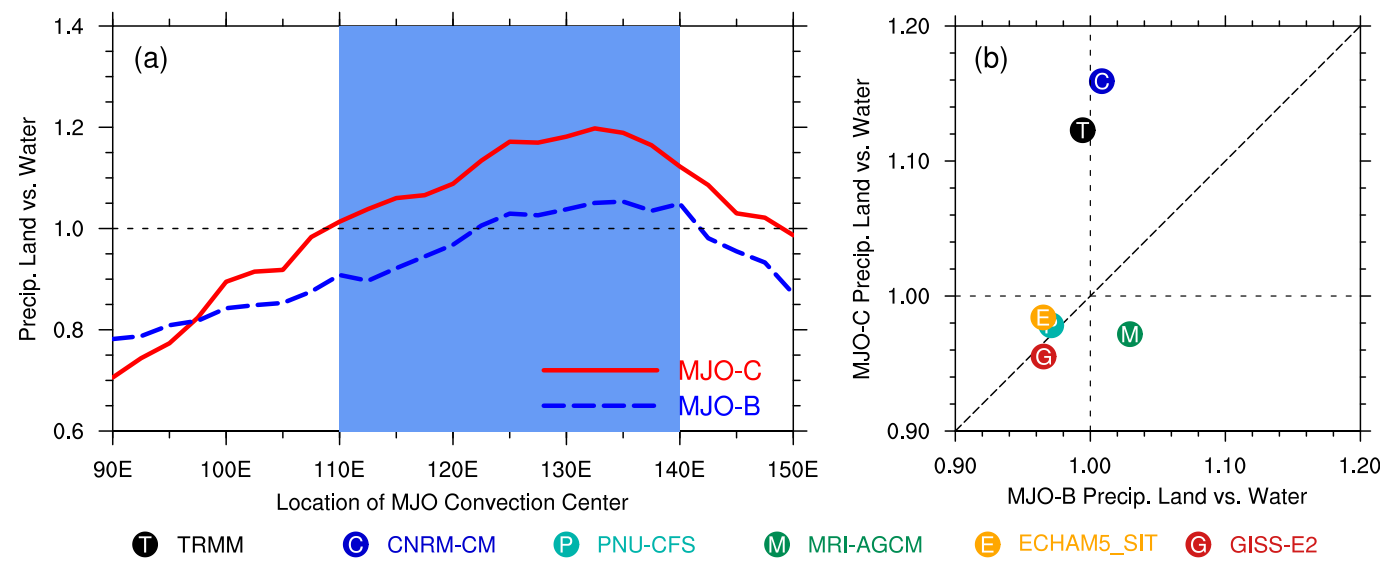

FIG. 17. (a) Ratio of averaged precipitation over the sea to land averaged over the $\mathrm{MC}\left(15^{\circ} \mathrm{S}-15^{\circ} \mathrm{N}, 100^{\circ}-150^{\circ} \mathrm{E}\right)$ for MJO-C and MJO-B in observations as the function of the longitude of the MJO convection center. (b) Scatter diagrams of averaged ratio in the observation and GCMs when $\mathrm{MJO}$ convection center is over $110^{\circ}-140^{\circ} \mathrm{E}$ for all tracked MJO-C events vs MJO-B events.

and blocking effects on MJO propagation by the MC in those GCMs are directly related. The blocking effect of the $\mathrm{MC}$, defined as the ratio of the number of MJO-B events to the total number of MJO events entering the $\mathrm{MC}$, varies from 0.22 to 1 among all GCMs during boreal winter (Fig. 5). It is exaggerated by most GCMs, but there are a few GCMs that produce weaker ones. Airsea coupling could be a potential factor to reduce the barrier effect on MJO propagation, but further studies are needed to confirm the result because the sample size of GCMs is limited in current study.

All tracked MJO events in this study propagate at least though a range of $50^{\circ}$. Therefore, some tracked eastward-propagating events that were blocked by the $\mathrm{MC}$ are not identified as MJO because their propagation ranges do not meet the criteria. The averaged MJO propagation range is relatively shorter in most GCMs than in the observation (Fig. 2a); therefore, the number of MJO-B events is underestimated in most GCMs. The barrier effect may be artificially underestimated to a certain extent because of the underestimated number of MJO-B, and it also may not be robust because of the limited sample sizes of MJO events in each GCM.

The possible reasons why MJO-C can overcome the barrier effect while MJO-B fails are examined for those GCMs that produce a relatively larger amount of MJO events within a 20 -yr simulation during boreal winter. The westward tilt is obvious in the vertical thermaldynamic structures of MJO, such as moisture, diabatic heating, and moisture flux convergence, in both MJO-C and MJO-B when MJO convection is over the Indian Ocean, but it was lost in MJO-B when MJO convection moves into the MC. The MJO-B event failed to propagate through the $\mathrm{MC}$ because of no obvious lowertropospheric premoistening ahead of its convection center when it is over the MC. Stronger lowertropospheric premoistening ahead of the convection center over the MC could lead the MJO-C to propagate through the MC. The stronger premoistening processes in MJO-C is mainly attributed to the stronger MJO vertical velocity acting on the vertical gradient of LFBS moisture $\left(-\omega^{\prime} \partial \bar{q} / \partial p\right)$. The stronger MJO vertical velocity in the lower troposphere ahead of an MJO convection center is partly related to the stronger diabatic heating release there, and partly to the stronger boundary layer convergence, especially its zonal component induced by the FWC $\left(-\partial u^{\prime} / \partial x\right)$. Furthermore, the FWC also transports the moisture from the boundary layer farther east to the convection center to the free atmosphere over the contiguous area of the MJO convection center. These results suggest that the amplitude of the lower-tropospheric zonal gradient of the easterly anomaly $\left(-\partial u^{\prime} / \partial x\right)$ in the eastern contiguous area of the MJO convection center could be a potential precursor to lead to the eastward propagation of the MJO.

The background SST and land-sea contrast of precipitation over the MC could also impact the barrier effects on eastward propagation of the MJO over the MC in the observation. However, the role of the background SST (Fig. 16) and diurnal cycle (Fig. 17) in the barrier effect on MJO propagation by the MC in most GCMs are not the same as in the observation. Most GCMs produce more precipitation (Fig. 17) over land than water in the MC both in MJO-C and MJO-B. The coarse resolution of the GCMs cannot well capture the localized air-sea interaction and diurnal cycle in convection over the MC. Higher-resolution GCMs are 
needed to study the potential role of SST and the diurnal cycle in the barrier effect on MJO propagation by the MC.

Acknowledgments. The authors thank three anonymous reviewers for an earlier version of this article. The authors thank the GASS-YoTC-MJO project for providing the model simulation data. This research was sponsored by the Key Research Program of Frontier Sciences of CAS through Grant QYZDBSSW-DQC017, the National Basic Research Program of China through Grant 2015CB453200, and the National Nature Science Foundation of China through Grants 41575062 and 41520104008.

\section{REFERENCES}

Andersen, J. A., and Z. Kuang, 2012: Moist static energy budget of MJO-like disturbances in the atmosphere of a zonally symmetric aquaplanet. J. Climate, 25, 2782-2804, https://doi.org/ 10.1175/JCLI-D-11-00168.1.

Chang, C. P., P. A. Harr, and H. J. Chen, 2005: Synoptic disturbances over the equatorial South China Sea and western maritime continent during boreal winter. Mon. Wea. Rev., 133, 489-503, https://doi.org/10.1175/MWR-2868.1.

Chen, G., and B. Wang, 2018: Effects of enhanced front Walker cell on the eastward propagation of the MJO. J. Climate, 31, 77197738, https://doi.org/10.1175/JCLI-D-17-0383.1.

Chen, S. S., B. E. Mapes, and R. A. Houze Jr., 1996: Multiscale variability of deep convection in relation to large-scale circulation in TOGA COARE. J. Atmos. Sci., 53, 1380-1409, https://doi.org/ 10.1175/1520-0469(1996)053<1380:MVODCI > 2.0.CO;2.

Chen, X., J. Ling, and C. Y. Li, 2016: Evolution of the Madden-Julian oscillation in two types of El Niño. J. Climate, 29, 1919-1934, https://doi.org/10.1175/JCLI-D-15-0486.1.

Dee, D. P., and Coauthors, 2011: The ERA-Interim reanalysis: Configuration and performance of the data assimilation system. Quart. J. Roy. Meteor. Soc., 137, 553-597, https://doi.org/ 10.1002/qj.828.

Feng, J., T. Li, and W. Zhu, 2015: Propagating and nonpropagating MJO events over Maritime Continent. J. Climate, 28, 84308449, https://doi.org/10.1175/JCLI-D-15-0085.1.

Fu, X., J. Y. Lee, B. Wang, W. Wang, and F. Vitart, 2013: Intraseasonal forecasting of the Asian summer monsoon in four operational and research models. J. Climate, 26, 4186-4203, https://doi.org/10.1175/JCLI-D-12-00252.1.

Hagos, S. M., C. Zhang, Z. Feng, C. D. Burleyson, C. De Mott, B. Kerns, J. J. Benedict, and M. N. Martini, 2016: The impact of the diurnal cycle on the propagation of Madden-Julian oscillation convection across the Maritime Continent. J. $A d v$. Model. Earth Syst., 8, 1552-1564, https://doi.org/10.1002/ 2016MS000725.

Hayashi, Y., and D. G. Golder, 1986: Tropical intraseasonal oscillations appearing in a GFDL general-circulation model and FGGE data. Part I: Phase propagation. J. Atmos. Sci., 43, 3058-3067, https://doi.org/10.1175/1520-0469(1986)043<3058: TIOAIA $>2.0 . \mathrm{CO} ; 2$

Hendon, H. H., B. Liebmann, M. E. Newman, J. D. Glick, and J. E. Schemm, 2000: Medium range forecasts errors associated with active episodes of the Madden-Julian oscillation. Mon.
Wea. Rev., 128, 69-86, https://doi.org/10.1175/1520-0493(2000) 128<0069:MRFEAW >2.0.CO;2.

Hirata, F. E., P. J. Webster, and V. E. Toma, 2013: Distinct manifestations of austral summer tropical intraseasonal oscillations. Geophys. Res. Lett., 40, 3337-3341, https://doi.org/ 10.1002/grl.50632.

Hsu, H.-H., and M. Y. Lee, 2005: Topographic effects on the eastward propagation and initiation of the Madden-Julian oscillation. J. Climate, 18, 795-809, https://doi.org/10.1175/ JCLI-3292.1.

Hsu, P.-C., and T. Li, 2012: Role of the boundary layer moisture asymmetry in causing the eastward propagation of the Madden-Julian Oscillation. J. Climate, 25, 4914-4931, https:// doi.org/10.1175/JCLI-D-11-00310.1.

, and Y. Yang, 2016: Contribution of atmospheric internal processes to interannual variability of South Asian summer monsoon. Int. J. Climatol., 36, 2917-2930, https://doi.org/ $10.1002 /$ joc. 4528 .

— , T. Li, and H. Murakami, 2014: Moisture asymmetry and MJO eastward propagation in an aqua-planet general circulation model. J. Climate, 27, 8747-8760, https://doi.org/10.1175/JCLID-14-00148.1.

Huffman, G. J., and Coauthors, 2007: The TRMM Multisatellite Precipitation Analysis (TMPA): Quasi-global, multiyear, combined-sensor precipitation estimates at fine scales. J. Hydrometeor., 8, 38-55, https://doi.org/10.1175/JHM560.1.

Hung, M. P., J. L. Lin, W. Wang, D. Kim, T. Shinoda, and S. J. Weaver, 2013: MJO and convectively coupled equatorial waves simulated by CMIP5 climate models. J. Climate, 26, 6185-6214, https://doi.org/10.1175/JCLI-D-12-00541.1.

Inness, P. M., and J. M. Slingo, 2006: The interaction of the Madden-Julian Oscillation with the Maritime Continent in a GCM. Quart. J. Roy. Meteor. Soc., 132, 1645-1667, https:// doi.org/10.1256/qj.05.102.

Jiang, X., and Coauthors, 2015: Vertical structure and physical processes of the Madden-Julian oscillation: Exploring key model physics in climate simulations. J. Geophys. Res., 120, 4718-4748, https://doi.org/10.1002/2014JD022375.

—, M. Zhao, E. D. Maloney, and D. E. Waliser, 2016: Convective moisture adjustment time scale as a key factor in regulating model amplitude of the Madden-Julian Oscillation. Geophys. Res. Lett., 43, 10 412-10 419, https://doi.org/10.1002/2016GL070898.

Kessler, W. S., and R. Kleeman, 2000: Rectification of the Madden-Julian oscillation into the ENSO cycle. J. Climate, 13, 3560-3575, https://doi.org/10.1175/1520-0442(2000)013<3560: ROTMJO $>2.0 . \mathrm{CO} ; 2$.

Kiladis, G. N., J. Dias, K. H. Straub, M. C. Wheeler, S. N. Tulich, K. Kikuchi, K. M. Weickmann, and M. J. Ventrice, 2014: A comparison of OLR and circulation-based indices for tracking the MJO. Mon. Wea. Rev., 142, 1697-1715, https://doi.org/ 10.1175/MWR-D-13-00301.1.

Kim, D., and Coauthors, 2009: Application of MJO simulation diagnostics to climate models. J. Climate, 22, 6413-6436, https://doi.org/10.1175/2009JCLI3063.1.

_ J. S. Kug, and A. H. Sobel, 2014: Propagating versus nonpropagating Madden-Julian oscillation events. J. Climate, 27, 111-125, https://doi.org/10.1175/JCLI-D-13-00084.1.

Lafleur, D. M., B. S. Barrett, and G. R. Henderson, 2015: Some climatological aspects of the Madden-Julian oscillation (MJO). J. Climate, 28, 6039-6053, https://doi.org/10.1175/ JCLI-D-14-00744.1.

Lau, N. C., and K.-M. Lau, 1986: Structure and propagation of intraseasonal oscillations appearing in a GFDL GCM. 
J. Atmos. Sci., 43, 2023-2047, https://doi.org/10.1175/15200469(1986)043<2023:TSAPOI>2.0.CO;2.

Li, C., Z. Long, and Q. Zhang, 2001: Strong/weak summer monsoon activity over the South China Sea and atmospheric intraseasonal oscillation. Adv. Atmos. Sci., 18, 1146-1160, https://doi.org/10.1007/s00376-001-0029-x.

— X. X. Jia, J. Ling, W. Zhou, and C. Zhang, 2009: Sensitivity of MJO simulations to diabatic heating profiles. Climate Dyn., 32, 167-187, https://doi.org/10.1007/s00382-008-0455-x.

Li, T., 2014: Recent advance in understanding the dynamics of the Madden-Julian oscillation. J. Meteor. Res., 28, 1-33, https:// doi.org/10.1007/s13351-014-3087-6.

Liebmann, B., H. H. Hendon, and J. D. Glick, 1994: The relationship between tropical cyclones of the western Pacific and Indian Oceans and the Madden-Julian oscillation. J. Meteor. Soc. Japan, 72, 401-412, https://doi.org/10.2151/jmsj1965.72.3_401.

Lin, J., and Coauthors, 2006: Tropical intraseasonal variability in 14 IPCC AR4 climate models. Part I: Convective signals. J. Climate, 19, 2665-2690, https://doi.org/10.1175/JCLI3735.1.

Lindzen, R. S., and S. Nigam, 1987: On the role of the sea surface temperature gradients in forcing low-level winds and convergence in the Tropics. J. Atmos. Sci., 44, 2440-2458, https://doi.org/ 10.1175/1520-0469(1987)044<2418:OTROSS >2.0.CO;2.

Ling, J., C. Zhang, and P. Bechtold, 2013: Large-scale distinctions between MJO and non-MJO convective initiation over the tropical Indian Ocean. J. Atmos. Sci., 70, 2696-2712, https:// doi.org/10.1175/JAS-D-13-029.1.

, P. Bauer, P. Bechtold, A. Beljaars, R. Forbes, F. Vitart, M. Ulate, and C. Zhang, 2014: Global versus local MJO forecast skill of the ECMWF model during DYNAMO. Mon. Wea. Rev., 142, 2228-2247, https://doi.org/10.1175/MWR-D-13-00292.1.

_ C. Zhang, S. Wang, and C. Li, 2017: A new interpretation of the ability of global models to simulate the MJO. Geophys. Res. Lett., 44, 5798-5806, https://doi.org/10.1002/2017GL073891.

,,-- R. Joyce, P.-P. Xie, and G. Chen, 2019: Possible role of the diurnal cycle in land convection in the barrier effect on the MJO by the Maritime Continent. Geophys. Res. Lett., 46, 3001-3011, https://doi.org/10.1029/2019GL081962.

Liu, F., L. Zhou, J. Ling, X. Fu, and G. Huang, 2016a: Relationship between SST anomalies and the intensity of intraseasonal variability. Theor. Appl. Climatol., 124, 847-854, https:// doi.org/10.1007/s00704-015-1458-2.

— T. T. Li, H. Wang, L. Deng, and Y. Zhang, 2016b: Modulation of boreal summer intraseasonal oscillation over the western North Pacific by the ENSO. J. Climate, 29, 7189-7201, https:// doi.org/10.1175/JCLI-D-15-0831.1.

Liu, P., Q. Zhang, C. Zhang, Y. Zhu, M. Khairoutdinov, H. M. Kim, C. Schumacher, and M. Zhang, 2016: A revised real-time multivariate MJO index. Mon. Wea. Rev., 144, 627-642, https://doi.org/10.1175/MWR-D-15-0237.1.

Madden, R. A., and P. R. Julian, 1971: Detection of a 40-50-day oscillation in zonal wind in tropical Pacific. J. Atmos. Sci., 28, 702-708, https://doi.org/10.1175/1520-0469(1971)028<0702: DOADOI $>2.0 . \mathrm{CO} ; 2$.

—_, and ——, 1972: Description of global-scale circulation cells in tropics with a 40-50 day period. J. Atmos. Sci., 29, 1109-1123, https://doi.org/10.1175/1520-0469(1972)029<1109: DOGSCC $>2.0 . \mathrm{CO} ; 2$.

Maloney, E. D., and A. H. Sobel, 2004: Surface fluxes and ocean coupling in the tropical intraseasonal oscillation. J. Climate, 17, 4368-4386, https://doi.org/10.1175/JCLI-3212.1.

Moncrieff, M. W., D. E. Waliser, M. J. Miller, M. A. Shapiro, G. R. Asrar, and J. Caughey, 2012: Multiscale convective organiza- tion and the YOTC virtual global field campaign. Bull. Amer. Meteor. Soc., 93, 1171-1187, https://doi.org/10.1175/BAMS-D11-00233.1.

Neale, R., and J. Slingo, 2003: The Maritime Continent and its role in the global climate: A GCM study. J. Climate, 16, 834-848, https://doi.org/10.1175/1520-0442(2003)016<0834: TMCAIR $>2.0 . \mathrm{CO} ; 2$.

Petch, J., D. Waliser, X. Jiang, P. K. Xavier, and S. Woolnough, 2011: A global model inter-comparison of the physical processes associated with the MJO. GEWEX News, Vol. 21, No. 3, International GEWEX Project Office, Silver Spring, MD, 3-5.

Reynolds, R. W., T. M. Smith, C. Liu, D. B. Chelton, K. S. Casey, and M. G. Schlax, 2007: Daily high-resolution-blended analyses for sea surface temperature. J. Climate, 20, 5473-5496, https://doi.org/10.1175/2007JCLI1824.1.

Seo, K. H., W. Wang, J. Gottschalck, Q. Zhang, J.-K. E. Schemm, W. R. Higgins, and A. Kumar, 2009: Evaluation of MJO forecast skill from several statistical and dynamical forecast models. J. Climate, 22, 2372-2388, https://doi.org/10.1175/ 2008JCLI2421.1.

Slingo, J., and Coauthors, 1996: Intraseasonal oscillations in 15 atmospheric general circulation models: Results from an AMIP diagnostic subproject. Climate Dyn., 12, 325-357, https://doi.org/10.1007/BF00231106.

Sobel, A. H., E. D. Maloney, G. Bellon, and M. F. Dargan, 2008: The role of surface heat fluxes in tropical intraseasonal oscillations. Nat. Geosci., 1, 653-657, https://doi.org/10.1038/ngeo312.

_ S. Wang, and D. Kim, 2014: Moist static energy budget of the MJO during DYNAMO. J. Atmos. Sci., 71, 4276-4291, https:// doi.org/10.1175/JAS-D-14-0052.1.

Sperber, K. R., J. M. Slingo, P. M. Inness, and W. K. M. Lau, 1997: On the maintenance and initiation of the intraseasonal oscillation in the NCEP/NCAR reanalysis and in the GLA and UKMO AMIP simulations. Climate Dyn., 13, 769-795, https:// doi.org/10.1007/s003820050197.

Vitart, F., and F. Molteni, 2010: Simulation of the Madden-Julian oscillation and its teleconnections in the ECMWF forecast system. Quart. J. Roy. Meteor. Soc., 136, 842-855, https:// doi.org/10.1002/qj.623.

Waliser, D. E., K. M. Lau, W. Stern, and C. Jones, 2003: Potential predictability of the Madden-Julian oscillation. Bull. Amer. Meteor. Soc., 84, 33-50, https://doi.org/10.1175/BAMS-84-1-33. , and Coauthors, 2009: MJO simulation diagnostics. J. Climate, 22, 3006-3030, https://doi.org/10.1175/2008JCLI2731.1.

_ - and Coauthors, 2012: The "year" of tropical convection (May 2008-April 2010): Climate variability and weather highlights. Bull. Amer. Meteor. Soc., 93, 1189-1218, https://doi.org/ 10.1175/2011BAMS3095.1.

Wang, B., and H. Rui, 1990: Dynamics of coupled moist KelvinRossby waves on an equatorial b-plane. J. Atmos. Sci., 47, 397-413, https://doi.org/10.1175/1520-0469(1990)047<0397: DOTCMK $>2.0 . \mathrm{CO} ; 2$.

— metric structures: Results from 24 GCM simulations. J. Climate, 30, 7933-7952, https://doi.org/10.1175/JCLI-D-16-0873.1.

Wang, L., T. Li, E. Maloney, and B. Wang, 2017: Fundamental causes of propagating and nonpropagating MJOs in MJOTF/ GASS models. J. Climate, 30, 3743-3769, https://doi.org/ 10.1175/JCLI-D-16-0765.1.

Wang, S., and A. H. Sobel, 2017: Factors controlling rain on small tropical islands: Diurnal cycle, large-scale wind speed, and topography. J. Atmos. Sci., 74, 3515-3532, https://doi.org/ 10.1175/JAS-D-16-0344.1. 
and - M. K. Tippett, and F. Vitart, 2019: Prediction and predictability of tropical intraseasonal convection: Seasonal dependence and the Maritime Continent prediction barrier. Climate Dyn., 52, 6015-6031, https://doi.org/10.1007/s00382018-4492-9.

Wang, W., M. P. Hung, S. Weaver, A. Kumar, and X. Fu, 2014: MJO prediction in the NCEP Climate Forecast System version 2. Climate Dyn., 42, 2509-2520, https://doi.org/10.1007/ s00382-013-1806-9.

Weaver, S. J., W. Wang, M. Chen, and A. Kumar, 2011: Representation of MJO variability in the NCEP Climate Forecast System. J. Climate, 24, 4676-4694, https://doi.org/10.1175/ 2011JCLI4188.1.

Wheeler, M. C., and H. H. Hendon, 2004: An all-season realtime multivariate MJO index: Development of an index for monitoring and prediction. Mon. Wea. Rev., 132, 19171932, https://doi.org/10.1175/1520-0493(2004)132<1917: AARMMI $>2.0 . \mathrm{CO} ; 2$.

—, and J. McBride, 2005: Australian-Indonesian monsoon. Intraseasonal Variability in the Atmosphere-Ocean Climate System, W. Lau and D. Waliser, Eds., Springer, 125-173.

Wu, C. H., and H. H. Hsu, 2009: Topographic influence on the MJO in the Maritime Continent. J. Climate, 22, 5433-5448, https:// doi.org/10.1175/2009JCLI2825.1.

Yanai, M., S. Esbensen, and J. H. Chu, 1973: Determination of bulk properties of tropical cloud clusters from large-scale heat and moisture budgets. J. Atmos. Sci., 30, 611-627, https://doi.org/ 10.1175/1520-0469(1973)030<0611:DOBPOT>2.0.CO;2.

Zhang, C., 2005: Madden-Julian oscillation. Rev. Geophys., 43, RG2003, https://doi.org/10.1029/2004RG000158.

$\longrightarrow$, 2013: Madden-Julian oscillation: Bridging weather and climate. Bull. Amer. Meteor. Soc., 94, 1849-1870, https://doi.org/ 10.1175/BAMS-D-12-00026.1.

— , and J. Gottschalck, 2002: SST anomalies of ENSO and the Madden-Julian oscillation in the equatorial Pacific. J. Climate, 15, 2429-2445, https://doi.org/10.1175/1520-0442(2002)015<2429: SAOEAT $>2.0 . \mathrm{CO} ; 2$.

— , and J. Ling, 2012: Potential vorticity of the Madden-Julian oscillation. J. Atmos. Sci., 69, 65-78, https://doi.org/10.1175/ JAS-D-11-081.1.

$\longrightarrow$, and — 2017: Barrier effect of the Indo-Pacific Maritime Continent on the MJO: Perspectives from tracking MJO precipitation. J. Climate, 30, 3439-3459, https://doi.org/10.1175/ JCLI-D-16-0614.1.

M. Dong, S. Gualdi, H. H. Hendon, E. D. Maloney, A. Marshall, K. R. Sperber, and W. Wang, 2006: Simulations of the Madden-Julian Oscillation by four pairs of coupled and uncoupled global models. Climate Dyn., 27, 573-592, https:// doi.org/10.1007/s00382-006-0148-2.

Zhao, C. B., T. Li, and T. J. Zhou, 2013: Precursor signals and processes associated with MJO initiation over the tropical Indian Ocean. J. Climate, 26, 291-307, https://doi.org/10.1175/ JCLI-D-12-00113.1. 